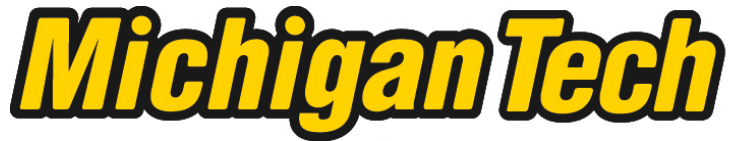 \\ Michigan Technological University Create the Future Digital Commons @ Michigan Tech
}

2013

EVALUATION AND MONITORING OF ASH (FRAXINUS SPP.) TOLERANT TO LONG-TERM EMERALD ASH BORER (AGRILUS PLANIPENNIS [COLEOPTERA: BUPRESTIDAE]) EXPOSURE

Kathryn G. Hietala

Michigan Technological University

Follow this and additional works at: https://digitalcommons.mtu.edu/etds

Part of the Ecology and Evolutionary Biology Commons, Entomology Commons, and the Natural Resources Management and Policy Commons

Copyright 2013 Kathryn G. Hietala

\section{Recommended Citation}

Hietala, Kathryn G., "EVALUATION AND MONITORING OF ASH (FRAXINUS SPP.) TOLERANT TO LONGTERM EMERALD ASH BORER (AGRILUS PLANIPENNIS [COLEOPTERA: BUPRESTIDAE]) EXPOSURE", Master's Thesis, Michigan Technological University, 2013.

https://doi.org/10.37099/mtu.dc.etds/664

Follow this and additional works at: https://digitalcommons.mtu.edu/etds

Part of the Ecology and Evolutionary Biology Commons, Entomology Commons, and the Natural Resources Management and Policy Commons 


\title{
EVALUATION AND MONITORING OF ASH (FRAXINUS SPP.) TOLERANT TO LONG-TERM EMERALD ASH BORER (AGRILUS PLANIPENNIS [COLEOPTERA: BUPRESTIDAE]) EXPOSURE
} By

Kathryn G. Hietala

\author{
A THESIS \\ Submitted in partial fulfillment of the requirements for the degree of \\ MASTER OF SCIENCE \\ In Forest Ecology and Management
}

MICHIGAN TECHNOLOGICAL UNIVERSITY

2013

(C) 2013 Kathryn G. Hietala 
This thesis has been approved in partial fulfillment of the requirements for the Degree of MASTER OF SCIENCE in Forest Ecology and Management.

School of Forest Resources and Environmental Science

Thesis Advisor:

Committee Member:

Committee Member:

School Dean:
Dr. Andrew J. Storer

Dr. Erika Hersch-Green

Dr. Jordan M. Marshall 


\section{Table of Contents}

List of Figures

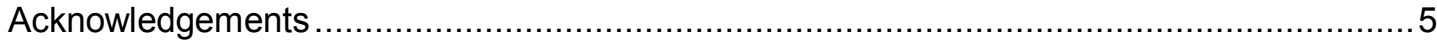

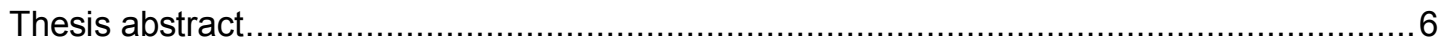

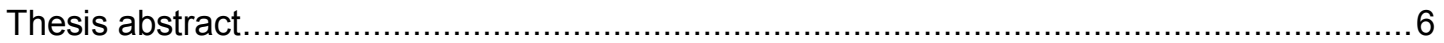

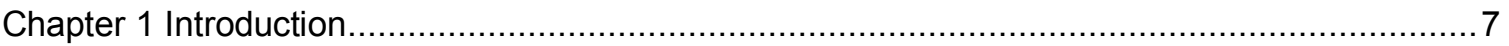

Invasive forest species - ecological and economic impact..................................... 7

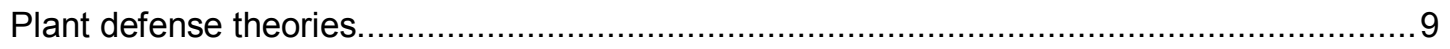

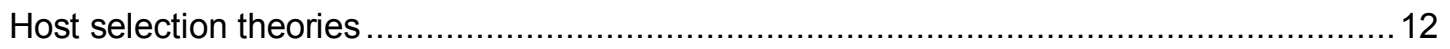

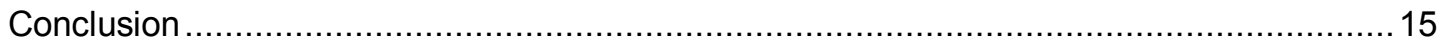

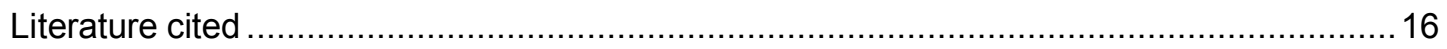

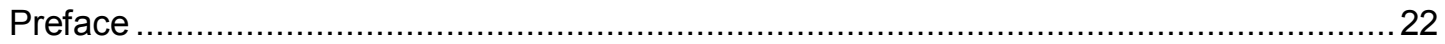

Chapter 2 Evaluation and monitoring of ash (Fraxinus spp.) tolerant to long-term emerald ash borer (Agrilus planipennis [Coleoptera: Buprestidae]) exposure ...........................................23

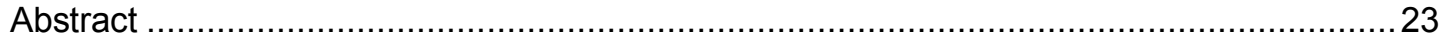

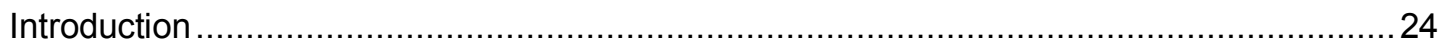

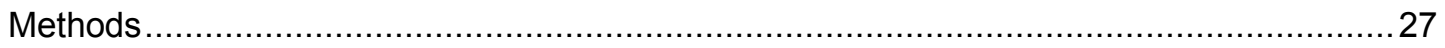

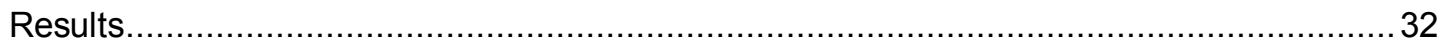

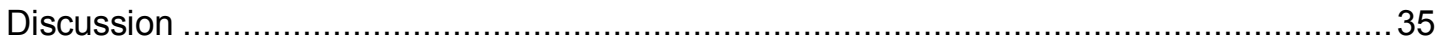

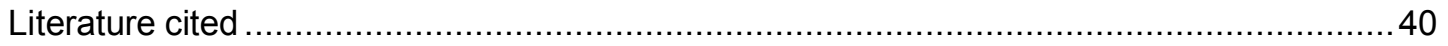




\section{List of Figures}

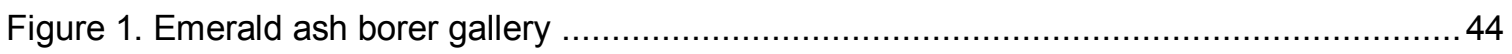

Figure 2. Individual trees in the intermediate tolerance group ............................................. 45

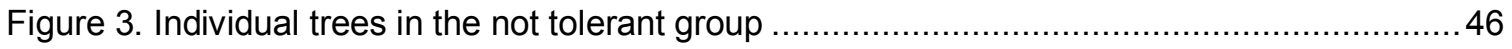

Figure 4. Individual trees in the apparently tolerant group ............................................. 47

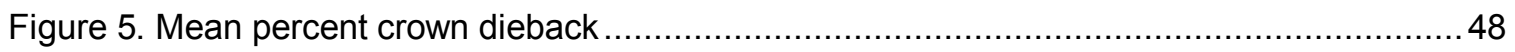

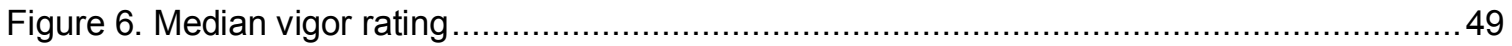

Figure 7. Number of trees with bark splits present .................................................... 50

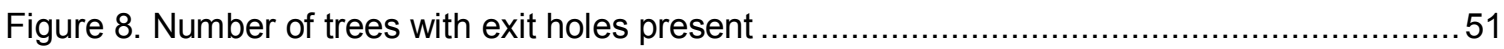

Figure 9. Number of trees with woodpecker damage present ............................................... 52

Figure 10. Number of trees with epicormic shoots present............................................... 53 


\section{Acknowledgements}

Completing a Master of Science program has probably been one of the most challenging tasks of my professional career and personal development. I have shared many highs and lows over the past two years with various people. It has been a great privilege to spend several years here in the School of Forest Resources and Environmental Science at Michigan Technological University, but holy wah is it time to go.

The following thesis was accomplished with the guidance and support from a number of people. I would like to thank Dr. Andrew Storer for his supervision of my M.S. degree and for his assistance in academic and research related issues. I would like to thank my committee members Dr. Jordan Marshall and Dr. Erika Hersch-Green for their advice and assistance. Their patience and contributions are much appreciated.

I would also like to thank the people in the Storer lab. Many who are not only peers and co-workers but have also become dear friends throughout this process. They have stuck with me despite many hours in the field and have been supportive despite the many interruptions and episodes of energy explosions into a very quiet lab setting. I owe a special thanks to Max Henschell for his support, both emotionally and academically always finding time to read many early drafts and providing useful critiques. And lastly, to my family despite not really understanding what I do, or why it takes so long, have always been very supportive and continues to strengthen my confidence as a student and as a person. 


\section{Thesis abstract}

Invasive insects that successfully establish in introduced areas can significantly alter natural communities. These pests require specific establishment criteria (e.g. host suitability) that, when known, can help quantify potential damage to infested areas. Emerald ash borer (Agrilus planipennis [Coleoptera: Buprestidae]) is an invasive phloem-feeding pest which is responsible for the death of millions of ash trees (Fraxinus spp. L.). Over 200 surviving ash trees were previously identified in the Huron-Clinton Metroparks located in southeast Michigan. Trees were assessed over a four year period and a hierarchical cluster analysis was performed on dieback, vigor, and presence of signs and symptoms, in order to place trees into one of three tolerance groups. The clustering of trees with different responses to emerald ash borer attack suggests that there are different tolerance levels in North American ash trees in southeastern Michigan, and these groups were designated as apparently tolerant, not tolerant and intermediate tolerance. Adult landing rates and evidence of adult emergence were significantly lower in the apparently tolerant group compared with the not tolerant group, but larval survival from eggs placed on trees did not differ between tolerance groups. Therefore, it appears that apparently tolerant trees survive because they are less attractive to adult beetles which results in fewer eggs being laid on them. Trees in the apparently tolerant group remained of higher vigor over the four years of the study. North American ash may survive the emerald ash borer epidemic due to natural variation and inherent resistance regardless of the lack of co-evolutionary history with emerald ash borer. 


\section{Chapter 1 Introduction}

\section{Invasive forest species - ecological and economic impact}

Outbreaks in phytophagous insect populations can cause significant ecological and economic impacts by damaging and altering natural ecosystems (Dukes et al. 2009, Kashian and Witter 2011), agricultural crops (Blake et al. 2010), or ecosystem services (Emmanuel 1997). Invasive phytophagous insects, in particular, can cause extensive damage (e.g. loss of important (Woods and Shanks 1959) if populations are not regulated by natural enemies (Niemela and Mattson 1996). There are approximately 450 invasive insects established in the United States, and among these, wood-boring insects cause the most economic damage (Aukema et al. 2011). Invasive pests, such as gypsy moth, hemlock woolly adelgid, and beech bark disease, have historically and are currently altering forest communities and have unknown long-term effects (Lovett et al. 2006, Dukes et al. 2009, Aukema et al. 2011). However, continued studies have identified resistance and tolerance in host trees and have begun to develop successful management strategies in response to these pests (Lovett et al. 2006). Some current silvicultural techniques, like road construction and clear cutting, may facilitate a higher frequency of invasive pest incidents by disturbing forests and encouraging early successional plants (Coyle et al. 2010).

In many cases, invasive phloem feeding and wood boring insects and native species can spread to available hosts naturally or with human assistance. For example, for wood bearing insects, human mediated movement commonly occurs via the transportation of firewood, which has assisted the spread of invasive beetles within the United States including soapberry borer (Agrilus prinurus Chevrolat [Coleoptera: Buprestidae]) in the South, goldspotted oak borer ( $A$. coxalis Waterhouse) in the West, and emerald ash borer (A. planipennis Fairmaire) in the Midwest and Northeast (Haack et al. 2010b). The intensity of these infestations varies depending on the relationship between host plant characteristics and insect life history traits, such as identifying stressed hosts or feeding on the cambium layer. These insect-plant relationships 
shape host plant evolution, specifically regarding whether a host is susceptible or resistant (Eyles et al. 2009). The outcomes of these relationships can potentially be managed to reduce or prevent damage (Eyles et al. 2009).

Invasive pests across all feeding guilds (i.e. borers, sap feeders, foliage feeders) can have profound effects on the composition of forest communities and cause lasting economic impacts (Haack et al. 2010a, Aukema et al. 2011). Invasive phloem and wood boring insects cause the highest economic damage in North America across different feeding guilds of invasive phytophagous insects (Haack et al. 2010b, Aukema et al. 2011). The economic impact of invasive species on forest communities have been recently quantified through federal and local government expenditures, household expenditures, residential property value loss, and forest landowner timber loss (Aukema et al. 2011, Kovacs et al. 2011). It was found that emerald ash borer may be one of the most costly pests, costing local governments up to $\$ 850$ million per year and forest landowners up to $\$ 60$ million per year; collective damage caused by emerald ash borer will cost about $\$ 1.7$ billion per year (Aukema et al. 2011). To put in perspective, this estimate equates to the entire budget request for the U.S. Fish and Wildlife Service (USFWS 2012). Without prevention and control the spread of emerald ash borer could cost $\$ 12.5$ billion to remove and replace ash trees in one decade (Kovacs et al. 2011).

Emerald ash borer was first discovered as a pest in North America in Detroit, Michigan in 2002, and continues to threaten natural species composition in forest communities and ash in urban landscapes (Haack 2002, Poland and McCullough 2006). Ash (Fraxinus spp.) are common urban street trees that have experienced high rates of emerald ash borer induced mortality, additionally, these trees have important value to residents in these infested areas (Poland and Mccullough 2006, Hunter 2011). This impact was made apparent when ten thousand ash were dead in Ann Arbor, Michigan, just five years after initial detection (Hunter 2011). In addition to financial costs, the loss of ash in North America could result in a negative effect on species composition in forest ecosystems (Kashian and Witter 2011) and native arthropod communities 
(Gandhi and Herms 2010a). Host-choice interactions are complex processes that are shaped by host characteristics (e.g. resistance, tolerance, constitutive defenses, or induced defenses) and the insects' role (e.g. searching, selection, preference, and recognition) (Schoonhoven et al. 2005). Insect damage can reduce host quality and elicit plant defenses which can influence host selection (Fujiyama et al. 2008)

\section{Plant defense theories}

Host condition is an important factor in shaping complex host-choice interactions (Schoonhoven et al. 2005). Trees have the ability to avoid or tolerate moderate biotic stressors while severe biotic stress can cause mortality (Hopkins 1995). Plant traits in combination with specific microenvironment conditions can make plants less apparent to herbivores, reducing the chance of discovery (Hester et al. 2006). However plants, such as trees, that are long-lived organisms commonly produce general defenses because they are apparent hosts. The plant apparency theory suggests that obvious plants have evolved mechanisms (e.g. lower nutritional value) to reduce attractiveness (Feeny 1976). In other words, the more apparent a plant is, the more quantitative and constitutive defenses it will have influencing plant quality and insect digestion. The preference of herbivores in host-choice interactions can be influenced by the wide range of variability within and across host species (Schoonhoven et al. 2005). Trees can have constitutive defenses which are present prior to experiencing biotic stress or they can respond after an attack with induced defenses, both physical and chemical (Kaitaniemi and Ruohomaki 2001). Constitutive defenses are present at all times and serve as a pre-existing protection (Heil 2009). This defense can reduce the impact of herbivores or other stressors by deflecting attacks and reducing vulnerability (Agrawal and Klein 2000). Constitutive physical defenses include different structural forms such as thorns, hairs, thick cuticles, bark features, or oils. Constitutive chemical defenses can be qualitative (e.g. toxins and alkaloids), which are found in lower concentrations, have a rapid turnover, and require large nitrogen investments (Baldwin et al. 1990). Or constitutive chemical defenses can be quantitative (e.g. phenolic compounds, acids, tannins, and 
lignins), which require a higher carbon investment to synthesize, transport and store (Howe and Schaller 2008). However there is a cost to the plant for both types of defensive chemicals (Stamp 2003).

In contrast to constitutive defenses, induced defenses are produced after an attack and protect the host tree from possible future ongoing attack or damage (Fujiyama et al. 2008). An example of a physical induced response can be seen when oak (Quercus spp.) form callus tissue in response to damage caused by phloem borers (Dunn et al. 1990). A chemical response is illustrated by the production of toxic or anti-feedant proteins or volatile organic compounds (VOC's), which serve as a signaling response to undamaged parts of the host, neighboring trees, and/or predators (Eyles et al. 2009). For example, hybrid poplar (Populus spp.) produced VOC's when fed on by gypsy moths inducing defenses on other potential hosts (Frost et al. 2007). There are three main host responses to stressors, tree resistance protects hosts by preventing attack, tree tolerance protects hosts by having the ability to maintain health by continuing to grow, reproduce, and repair herbivore induced injury, while susceptible hosts experience a decline in condition (Schoonhoven et al. 2005). Different species have different responses to biotic and abiotic stressors as well as individuals within a species.

There are 16 native species of ash in North America (USDA NRCS 2004) that serve as important timber trees, packing products, and wildlife habitat, and are potential hosts to emerald ash borer infestations. There is a host preference gradient between the four most common North American species, where green ash (Fraxinus pennsylvanica Marshall) is the most preferred species by emerald ash borer followed in decreasing preference by white ( $F$. Americana L.), black (F. nigra Marshall), and blue (F. quadrangulata Michx.) (Pureswaran and Poland 2009). Ash are a principal component to the overstory in multiple forest communities: white ash represents $11 \%$ in upland forests and $7 \%$ in dry-mesic forest types, green ash represents $8 \%$ in riparian floodplains, and black ash represents 15\% in deciduous swamps types in lower Michigan (Cappaert et al. 2005, Kashian and Witter 2011). Emerald ash borer infested stands frequently result in increased 
mortality of overstory trees that cause a higher frequency in large canopy gaps (Gandhi and Herms 2010b). These gaps can have direct and indirect effects such as potentially shifting nutrient cycling, decreasing forest diversity, and creating conditions that are more conducive to additional invasive plants and insects (Gandhi and Herms 2010a, 2010b). Recent studies suggest that the loss of ash in forest communities will have substantial effects on native species diversity. For example, of the 300 native arthropod species associated with ash, it is estimated that nearly $15 \%$ could become threatened if there is a major decline of ash on the landscape (Gandhi and Herms 2010a).

Ash has both constitutive and inducible defenses. Constitutive chemical defenses are present in ash which include defensive phenolics and volatile organic compounds that play a role in determining emerald ash borer oviposition preference (Cipollini et al. 2011). Adult emerald ash borer have been shown to respond to several VOC's (e.g. bark sesquiterpenes and green leaf volatiles) produced by ash and pheromones (e.g. lactone isomers) produced by female borers (Silk et al. 2011). Therefore, it is likely that leaf phenolics serve as a signal to the adult beetle with information regarding host suitability. Manchurian ash (F. mandshurica Rupr), that is native to Asia, is more resilient than North American ash trees (Eyles et al. 2007). The co-evolutionary history between Asian ash and emerald ash borer has shaped a unique complex of defensive phenolics which may play a role in resistance shown by low infestation rates and resilience shown by low mortality rates (Eyles et al. 2007, Rebek et al. 2008). Phenolic compounds differ between North American ash and Asian ash, however, the mechanism behind observed interspecific resistance is still unknown (Cipollini et al. 2011). Host tree defenses are often a combination of chemical defenses and/or physical barriers (Schoonhoven et al. 2005)

It is possible that a range in physical characteristics serve as part of an arsenal for constitutive defenses and possibly deter emerald ash borer oviposition (Anulewicz et al. 2008, Marshall et al. 2013). Female host-choice can be influenced by previous experience that shape subsequent choices regarding oviposition location (Schoonhoven et al. 2005). This is evident 
when plant structures that offer protection from natural elements influence the oviposition preference, as seen by the invasive cactus moth (Cactoblastis cactorum [Lepidoptera: Pyralidae]) (Jezorek et al. 2010). Physical plant structures influence emerald ash borer host-choice, females were observed ovipositing on rough bark seven times more than on smooth bark (Wei et al. 2007). Additionally, green ash with rough bark had more dense galleries and higher infestation where all available phloem was consumed than white ash (Anulewicz et al. 2008).

\section{Host selection theories}

Host-choice interactions are very complex and insect choice is an important component shaping these interactions (Schoonhoven et al. 2005). Host-choice, either acceptance or rejection, takes place when either oviposition or feeding occurs (Schoonhoven et al. 2005). For this reason, there are two key hypotheses that describe host-choice decisions: the preference-performance hypothesis and the optimal foraging hypothesis. The preference-performance hypothesis (larval success) suggests that adult insects choose host plants in order to maximize progeny success (Thompson 1988). Support for the preference-performance hypothesis is seen by the common leaf beetle (Gonioctena linnaeana Schrank [Coleoptera: Chrysomelidae]) where larval success was greater on female preferred willow (Salix spp.) (Wennström et al. 2010). The less preferred, less suitable hosts had higher concentrations of polyphenols (tannins and catechins), which reduced larval fitness (Wennström et al. 2010). Another host choice study found that adult leaf beetles (Cassida canaliculata Laich. [Coleoptera: Chrysomelidae]) chose larger host plants that increase larval success (Heisswolf et al. 2005). However, it is has also been shown that adult host choice is not always based primarily on larval success. The optimal foraging hypothesis suggests that adult insects choose host plants to maximize individual adult fitness regardless of progeny success (Stephen and Krebs 1986). For example, hawkmoth (Manduca sexta L. [Lepidoptera: Sphingidae]) females chose to oviposit on larger leaves that are more accessible, even though higher hatch rates were seen on smaller leaves (Potter et al. 2012). Insect hostchoice interactions may be explained by multiple underlying mechanisms (Scheirs 2002). 
Many mechanisms such as, trophic level effects, plant characteristics, and specific insect life-history traits, alone or in combination, can shape adult host-choices (Heisswolf et al. 2005). Host selection, by the willow-leaf beetle (Plagiodera versicolora (Laicharting) [Coleoptera: Chrysomelidae]), was influenced by the presence of enemies (Egusa et al. 2008). Additionally, the distribution of individual host plants can influence herbivory patterns (Schuldt et al. 2012). Furthermore, the co-evolutionary arms race, that occurs between insects and plants shapes these host-choice interactions as a result of codependent species adapting to changes in the other (Fujiyama et al. 2008). The integrated relationship between insect and plant develops over time and is sometimes a result of adaptive learning.

Mechanisms behind insect host-choice interactions may vary for invasive pests in an introduced range. Established invasive pest populations have the potential to cause widespread tree mortality and threaten the ecological stability of susceptible hosts (Dukes et al. 2009). One invasive pest can threaten multiple species. For example, Asian longhorned beetle (Anoplophora glabripennis) and citrus longhorned beetle (Anoplophora chinesis) threaten important lumber trees such as maple (Acer), elm (Ulmus), willow (Salix), chestnut (Aesculus), and ash (Fraxinus) (Haack et al. 2010a). In natural field conditions the oviposition behavior of the adult determines larval host conditions (Jezorek et al. 2010). These relationships are shaped directly and indirectly by plant traits and their effect on predators, parasites, or oviposition sites (Takeuchi et al. 2005). The host-choice interaction, acceptance or rejection, is based on characteristics of an individual host. Physical plant traits and chemical cues influence host-choice in the adult stage of many Coleopteran species (Schoonhoven et al. 2005). A strong correlation is seen between adult preference and larval success when feeding and oviposition sites are similar (Fujiyama et al. 2008), however different insect life stages may utilize their host in different ways.

Adult emerald ash borer do not cause severe direct damage to their host because they feed on vegetative parts (Haack et al. 2002, Poland and McCullough 2006). Eggs are laid in bark crevices and on hatching the larvae tunnel into the bark of the tree (Wang et al. 2010). The larvae 
causes considerable damage to their host by feeding on the phloem and boring into the xylem to overwinter, resulting in high rates of host mortality (Wei et al. 2007, Pureswaran and Poland 2009, Chen et al. 2011a). Emerald ash borer completes its life cycle in one or two years (Liu et al. 2007, Wei et al. 2007). Extensive larval feeding can cause tree death in one to three years (Poland and Mccullough 2006).

Adult emerald ash borer primarily attack stressed trees in their native range in Asia but as an invasive pest they have the ability to attack healthy ash in North America (Wei et al. 2007, Rebek et al. 2008). This suggests that any defenses evolved in North American ash for native buprestid pests are not effective for conferring resistance to emerald ash borer. The different concentrations of secondary metabolites, varying phloem chemistry, and lignin compounds (Eyles et al. 2007), suggest that North American ash trees require a different defense strategy to deter emerald ash borer. Exotics pests, such as emerald ash borer, lack co-evolutionary relationships with native North American species. The lack of host defense traits or predators can lead to devastating effects since these types of co-evolutionary relationships are vital factors in the regulation of pest populations (Liu et al. 2003, Rebek et al. 2008, Nielsen et al. 2011).

Host plant resistance and natural enemies are important factors influencing herbivorous insect populations (Schoonhoven et al. 2005). Host resistance to an insect is rarely based on one single resistance gene or trait but on a complex system of defenses (e.g. chemical, physical, and inadequate nutrition) (Schoonhoven et al. 2005). Emerald ash borer preference may be shaped by current infestation levels, sun exposure, and physical host traits (Anulewicz et al. 2008). Current management aims to decrease emerald ash borer populations through biological control procedures by introducing parasitic wasps (Bauer et al. 2008, Ulyshen et al. 2010, 2011, Duan et al. 2012). These wasps parasitize emerald ash borer eggs and larvae and may have direct effects, by reducing populations, and/or indirect effects, by influencing adult host choice and oviposition preference. As of 2013 , the biological control efforts are showing some success in 
southern Michigan where Tetrastichus planipennisi (Hymenoptera: Eulophidae) has established and is reducing emerald ash borer populations (Duan et al. 2013).

\section{Conclusion}

Invasive insects that successfully establish can negatively alter natural communities (Gandhi and Herms 2010a, 2010b) and understanding the establishment requirements can help estimate the extent of the damage by identifying suitable and unsuitable hosts. Studying host-choice interactions can also lead to a better understanding of the selective pressures behind the evolution of host-choice including fitness trade-offs and the adaptable nature of natural selection (Scheirs 2002). Defenses in conifer species to bark and wood boring insects have been extensively studied, however less is known about defenses of angiosperms to insect attacks (Cipollini et al, 2011). Ash defenses can occur as constitutive chemical (e.g. phloem content), constitutive physical (e.g. bark traits), induced chemical (e.g. defense proteins and phenolics), or induced physical defenses (e.g. calloused tissue) (Eyles et al. 2007).

Species-specific phenolic compounds and the co-evolutionary history between emerald ash borer and Manchurian ash (Fraxinus mandshurica Rupr.) have been studied regarding interspecific resistance preventing herbivory (Whitehill et al. 2011). Ash regeneration is essential for future stands (Kashian and Witter 2011), however, little is known regarding the mature trees that have survived the emerald ash borer epidemic in the Detroit-metro area (Marshall et al. 2013). Previous studies in heavily infested areas have found ash mortality to be almost $100 \%$, but suggest that the survival and establishment of ash regeneration will retain the ash component in forest communities (Kashian and Witter 2011).

The Huron-Clinton Metroparks are located in southeastern Michigan near the original infestation of emerald ash borer. Some of the host trees within this population are heavily infested with the following signs and symptoms: severe crown dieback, exit holes, and bark splits exposing galleries. However, some adjacent trees may have few or no feeding larvae which is 
evident by a low vigor rating (i.e. healthy) and a lack of signs or symptoms (Marshall et al. 2013). These observations suggest within-population variation in host quality that is reflected by the selective behavior of emerald ash borer females. These surviving ash trees may have a tolerant or resistant trait which is responsible for disrupting the emerald ash borer life cycle and could potentially provide an essential seed source for future generations.

The research reported in this thesis aims to identify and compare patterns in host survivorship in an area of extensive emerald ash borer damage. The identification of resilient trees could be used to create risk models and assist in future emerald ash borer control efforts. A further understanding of host-choice interactions, especially with invasive species, could assist in quick response and appropriate management of infestations. Incorporating new knowledge aims to save resources and prevent unnecessary costs.

\section{Literature cited}

Agrawal, A. A., \& Klein, C. N. (2000). What omnivores eat: direct effects of induced plant resistance and herbivores and indirect consequences for diet selection by omnivores. Journal of Animal Ecology, 69(3), 525-535.

Anulewicz, A. C., Mccullough, D. G., Cappaert, D. L., \& Poland, T. M. (2008). Host range of the emerald ash borer (Agrilus planipennis Fairmaire) (Coleoptera: Buprestidae) in North America: results of multiple-choice field experiments. Entomological Society of America, $37(1), 230-241$.

Aukema, J. E., Leung, B., Kovacs, K., Chivers, C., Britton, K. O., Englin, J., Frankel, S. J., et al. (2011). Economic impacts of non-native forest insects in the continental United States. PloS one, 6(9), e24587. doi:10.1371/journal.pone.0024587

Baldwin, I. T., Sims, C. L., \& Kean, S. E. (1990). The reproductive consequences associated with inducible alkaloidal responses in wild tobacco. Ecology, 71(1), 252-262.

Bauer, L. S., Liu, H., Miller, D., \& Gould, J. (2008). Developing a classical biological control program for Agrilus planipennis (Coleoptera: Buprestidae), an invasive ash pest in North America. Newsletter of the Michigan Entromological Society, pp. 38-39.

Blake, a. J., Dosdall, L. M., \& Keddie, B. a. (2010). Bottom-up effects of Brassica napus nutrition on the oviposition preference and larval performance of Ceutorhynchus obstrictus (Coleoptera: Curculionidae). Arthropod-Plant Interactions, 5(1), 39-48. doi:10.1007/s11829010-9114-3 
Chen, Y., Ciaramitaro, T., \& Poland, T. M. (2011). Moisture content and nutrition as selection forces for emerald ash borer larval feeding behaviour. Ecological Entomology, 36(3), 344354. doi:10.1111/j.1365-2311.2011.01278.x

Cipollini, D., Wang, Q., Whitehill, J. G. A., Powell, J. R., Bonello, P., \& Herms, D. A. (2011). Distinguishing defensive characteristics in the phloem of ash species resistant and susceptible to emerald ash borer. Journal of chemical ecology, 37(5), 450-9. doi:10.1007/s10886-011-9954-z

Coyle, D. R., Jordan, M. S., \& Raffa, K. F. (2010). Host plant phenology affects performance of an invasive weevil, Phyllobius oblongus (Coleoptera: Curculionidae), in a northern hardwood forest. Environmental entomology, 39(5), 1539-44. doi:10.1603/EN09381

Duan, J. J., Bauer, L. S., Abell, K. J., Lelito, J. P., \& Van Driesche, R. (2013). Establishment and abundance of Tetrastichus planipennisi (Hymenoptera: Eulophidae) in Michigan: potential for success in classical biocontrol of the invasive emerald ash borer (Coleoptera: Buprestidae). Journal of Economic Entomology, 106(3), 1145-1154. doi:10.1603/EC13047

Duan, J. J., Bauer, L. S., Hansen, J. a., Abell, K. J., \& Van Driesche, R. (2012). An improved method for monitoring parasitism and establishment of Oobius agrili (Hymenoptera: Encyrtidae), an egg parasitoid introduced for biological control of the emerald ash borer (Coleoptera: Buprestidae) in North America. Biological Control, 60(3), 255-261. doi:10.1016/j.biocontrol.2011.11.007

Dukes, J. S., Pontius, J., Orwig, D., Garnas, J. R., Rodgers, V. L., Brazee, N., Cooke, B., et al. (2009). Responses of insect pests, pathogens, and invasive plant species to climate change in the forests of northeastern North America: What can we predict? Canadian Journal of Forest Research, 39(2), 231-248. doi:10.1139/X08-171

Dunn, J. P., Potter, D. A., \& Kimmerer, T. W. (1990). Carbohydrate reserves, radial growth , and mechanisms of resistance of oak trees to phloem-boring insects. Oecologia, 83, 458-468.

Egusa, S., Nishida, T., Sawada, H., \& Fujisaki, K. (2008). Is selection of host plants by Plagiodera versicolora based on plant-related performance? Entomologia Experimentalis et Applicata, 128(2), 258-264. doi:10.1111/j.1570-7458.2008.00729.x

Emmanuel, R. (1997). Urban vegetational change as an indicator of demographic trends in cities: the case of Detroit. Environment \& Planning, 24, 415-426.

Eyles, A., Bonello, P., Ganley, R., \& Mohammed, C. (2009). Induced resistance to pests and pathogens in trees. The New phytologist, 185(4), 893-908. doi:10.1111/j.14698137.2009.03127.x

Eyles, A., Jones, W., Riedl, K., Cipollini, D., Schwartz, S., Chan, K., Herms, D. a, et al. (2007). Comparative phloem chemistry of Manchurian (Fraxinus mandshurica) and two North American ash species (Fraxinus americana and Fraxinus pennsylvanica). Journal of chemical ecology, 33(7), 1430-48. doi:10.1007/s10886-007-9312-3

Feeny, P. O. (1976). Plant apparency and chemical defense. In J. W. Wallace \& R. L. Mansell (Eds.), Recent Advances in Phytochemistry (pp. 1-40). Plenum, New York. 
Frost, C. J., Appel, H. M., Carlson, J. E., De Moraes, C. M., Mescher, M. C., \& Schultz, J. C. (2007). Within-plant signalling via volatiles overcomes vascular constraints on systemic signaling and primes responses against herbivores. Ecology letters, 10(6), 490-8. doi:10.1111/j.1461-0248.2007.01043.x

Fujiyama, N., Torii, C., Akabane, M., \& Katakura, H. (2008). Oviposition site selection by herbivorous beetles: a comparison of two thistle feeders, Cassida rubiginosa and Henosepilachna niponica. Entomologia Experimentalis et Applicata, 128(1), 41-48. doi:10.1111/j.1570-7458.2008.00712.x

Gandhi, K. J. K., \& Herms, D. a. (2010a). North American arthropods at risk due to widespread Fraxinus mortality caused by the alien emerald ash borer. Biological Invasions, 12(6), 18391846. doi:10.1007/s10530-009-9594-1

Gandhi, K. J. K., \& Herms, D. a. (2010b). Direct and indirect effects of alien insect herbivores on ecological processes and interactions in forests of eastern North America. Biological Invasions, 12(2), 389-405. doi:10.1007/s10530-009-9627-9

Haack, R. a, Hérard, F., Sun, J., \& Turgeon, J. J. (2010). Managing invasive populations of Asian longhorned beetle and citrus longhorned beetle: a worldwide perspective. Annual review of entomology, 55, 521-46. doi:10.1146/annurev-ento-112408-085427

Haack, R. a., Petrice, T. R., \& Wiedenhoeft, A. C. (2010). Incidence of bark- and wood-boring insects in firewood: a survey at Michigan's Mackinac Bridge. Journal of Economic Entomology, 103(5), 1682-1692. doi:10.1603/EC10041

Heil, M. (2009). Plastic defence expression in plants. Evolutionary Ecology, 24(3), 555-569. doi:10.1007/s10682-009-9348-7

Heisswolf, A., Obermaier, E., \& Poethke, H. J. (2005). Selection of large host plants for oviposition by a monophagous leaf beetle: nutritional quality or enemy-free space? Ecological Entomology, 30, 299-306.

Hester, A. J., Bergman, M., lason, G. R., \& Moen, J. (2006). Impacts of large herbivores on plant community structure and dynamics. In K. Danell, P. Duncan, R. Bergstrom, \& J. Pastor (Eds.), Large Herbivore Ecology, Ecosystem Dynamics and Conservation (pp. 97-111). Cambridge University Press.

Hopkins, W. J. (1995). The physiology of plants under stress. Introduction to plant physiology (pp. 451-475). University of Michigan. Ann Arbor, Michigan: J. Wiley.

Howe, G. A., \& Schaller, A. (2008). Direct defenses in plants and their induction by wounding by insect herbivores. Induced Plant Resistance to Herbivory (pp. 7-29). Springer Science+Business Media.

Hunter, M. R. (2011). Impact of ecological disturbance on awareness of urban nature and sense of environmental stewardship in residential neighborhoods. Landscape and Urban Planning, 101(2), 131-138. doi:10.1016/j.landurbplan.2011.02.005

Jezorek, H. a, Stiling, P. D., \& Carpenter, J. E. (2010). Targets of an invasive species: oviposition preference and larval performance of Cactoblastis cactorum (Lepidoptera: Pyralidae) on 14 
North American opuntioid cacti. Environmental entomology, 39(6), 1884-92.

doi:10.1603/EN10022

Kaitaniemi, P., \& Ruohomaki, K. (2001). Sources of variability in plant resistance against insects: free caterpillars show strongest effects. Oikos, 95(3), 461-470.

Kashian, D. M., \& Witter, J. a. (2011). Assessing the potential for ash canopy tree replacement via current regeneration following emerald ash borer-caused mortality on southeastern Michigan landscapes. Forest Ecology and Management, 261(3), 480-488. doi:10.1016/j.foreco.2010.10.033

Kovacs, K. F., Mercader, R. J., Haight, R. G., Siegert, N. W., McCullough, D. G., \& Liebhold, A. M. (2011). The influence of satellite populations of emerald ash borer on projected economic costs in U.S. communities, 2010-2020. Journal of environmental management, 92(9), 2170-81. doi:10.1016/j.jenvman.2011.03.043

Liu, H., Bauer, L. S., Gao, R., Zhao, T., Petrice, T. R., \& Haack, R. A. (2003). Exploratory survey for the emerald ash borer, Agrilus planipennis (Coleoptera: Buprestidae), and its natural enemies in China. The Great Lakes Entomologist, 36(3 \& 4), 191-204.

Liu, H., Bauer, L. S., Miller, D. L., Zhao, T., Gao, R., Song, L., Luan, Q., et al. (2007). Seasonal abundance of Agrilus planipennis (Coleoptera: Buprestidae) and its natural enemies Oobius agrili (Hymenoptera: Encyrtidae) and Tetrastichus planipennisi (Hymenoptera: Eulophidae) in China. Biological Control, 42(1), 61-71. doi:10.1016/j.biocontrol.2007.03.011

Lovett, G. M., Canham, C. D., Arthur, M. a., Weathers, K. C., \& Fitzhugh, R. D. (2006). Forest ecosystem responses to exotic pests and pathogens in Eastern North America. BioScience, 56(5), 395. doi:10.1641/0006-3568(2006)056[0395:FERTEP]2.0.CO;2

Marshall, J. M., Smith, E. L., Mech, R., \& Storer, A. J. (2013). Estimates of Agrilus planipennis infestation rates and potential survival of ash. American Midland Naturalist, 169, 179-193.

Nielsen, D. G., Muilenburg, V. L., \& Herms, D. a. (2011). Interspecific variation in resistance of Asian, European, and North American birches (Betula spp.) to bronze birch borer (Coleoptera: Buprestidae). Environmental Entomology, 40(3), 648-53. doi:10.1603/EN10227

Niemela, P., \& Mattson, W. J. (1996). Invasion of North American forests by European phytophagous insects. American Institute of Biological Sciences, 46(10), 741-753.

Poland, T. M., \& Mccullough, D. G. (2006). Emerald ash borer: invasion of the urban forest and the threat to North America 's ash resource. Journal of Forestry, (April/May), 118-124.

Potter, K. a., Bronstein, J., \& Davidowitz, G. (2012). Choice of oviposition sites by Manduca sexta and its consequences for egg and larval performance. Entomologia Experimentalis et Applicata, 144(3), 286-293. doi:10.1111/j.1570-7458.2012.01289.x

Pureswaran, D. S., \& Poland, T. M. (2009). Host selection and feeding preference of Agrilus planipennis (Coleoptera: Buprestidae) on ash (Fraxinus spp.). Environmental Entomology, 38(3), 757-765. doi:10.1603/022.038.0328 
Rebek, E. J., Herms, D. A., \& Smitley, D. R. (2008). Interspecific variation in resistance to emerald ash borer (Coleoptera : Buprestidae) among North American and Asian ash (Fraxinus spp.). Environmental Entomology, 37(1), 242-246.

Scheirs, J. (2002). Integrating optimal foraging and optimal oviposition theory in plant-insect research. Oikos, 96(1), 187-191.

Schoonhoven, L. M., Van Loon, J. J. A., \& Dicke, M. (2005). Insect-Plant Biology (2nd ed., pp. 135-232). New York: Oxford University Press Inc.

Schuldt, A., Bruelheide, H., Durka, W., Eichenberg, D., Fischer, M., Kröber, W., Härdtle, W., et al. (2012). Plant traits affecting herbivory on tree recruits in highly diverse subtropical forests. Ecology letters, 15(7), 732-9. doi:10.1111/j.1461-0248.2012.01792.x

Silk, P. J., Ryall, K., Mayo, P., Lemay, M. a, Grant, G., Crook, D., Cossé, A., et al. (2011). Evidence for a volatile pheromone in Agrilus planipennis Fairmaire (Coleoptera: Buprestidae) that increases attraction to a host foliar volatile. Environmental entomology, 40(4), 904-16. doi:10.1603/EN11029

Stamp, N. (2003). Out of the quagmire of plant defense hypotheses. The Quarterly review of biology, 78(1), 23-55. Retrieved from http://www.ncbi.nlm.nih.gov/pubmed/12661508

Stephen, D. W., \& Krebs, J. R. (1986). Foraging Theory. Princeton, New Jersey: Princeton Academic Press. Retrieved from http://books.google.com/books?hl=en\&lr=\&id=DVxvuqDsalC\&oi=fnd\&pg=PR9\&dq=optimal+foraging+stephens+and+krebs+1986\&ots=qWB4gw muoQ\&sig=B3KdQgFO_VLY15yrcQzOz4INPXA\#v=onepage\&q=optimal foraging stephens and krebs 1986\&f=false

Takeuchi, M., Kishikawa, H., \& Tamura, M. (2005). Host use in relation to food availability and larval development in the specialist herbivore Epilachna admirabilis (Coleoptera:

Coccinelidae). Applied Entomology and Zoology, 40(1), 177-184. doi:10.1303/aez.2005.177

Thompson, J. N. (1988). Evolutionary ecology of the relationship between oviposition preference and performance of offspring in phytophagous insects. Entomologia Experimentalis et Applicata, 47, 3-14.

Ulyshen, M. D., Duan, J. J., \& Bauer, L. S. (2010). Interactions between Spathius agrili (Hymenoptera: Braconidae) and Tetrastichus planipennisi (Hymenoptera : Eulophidae), larval parasitoids of Agrilus planipennis (Coleoptera : Buprestidae). Biological Control, 52(2), 188-193. doi:10.1016/j.biocontrol.2009.10.017

Ulyshen, M. D., Duan, J. J., Bauer, L. S., Gould, J., Taylor, P., Bean, D., Holko, C., et al. (2011). Field-cage methodology for evaluating climatic suitability for introduced wood-borer parasitoids: Preliminary results from the emerald ash borer system. Journal of Insect Science, 11(141), 1-10.

USDA NRCS. (2004). The PLANTS database version 3.5. National Plant Data Center. Retrieved May 8, 2013, from http://plants.usda.gov/java/

USFWS. (2012). President requests $\$ 1.7$ billion for U.S. Fish and Wildlife Service in Fiscal Year (FY) 2012. Office of External Affairs: Virtual News Room. Retrieved from 
http://us.vocuspr.com/Newsroom/Query.aspx?SiteName=fws\&Entity=PRAsset\&SF_PRAsse t_PRAssetID_EQ=113088\&XSL=PressRelease \&Cache=True

Wang, X.-Y., Yang, Z.-Q., Gould, J. R., Zhang, Y.-N., Liu, G.-J., \& Liu, E. (2010). The biology and ecology of the emerald ash borer, Agrilus planipennis, in China. Journal of insect science (Online), 10(128), 128. doi:10.1673/031.010.12801

Wei, X., Wu, Y., Reardon, R., Sun, T.-H., Lu, M., \& Sun, J.-H. (2007). Biology and damage traits of emerald ash borer (Agrilus planipennis Fairmaire) in China. Insect Science, 14(5), 367373. doi:10.1111/j.1744-7917.2007.00163.x

Wennström, A., Niemi Hjulström, L., Hjältén, J., \& Julkunen-Tiitto, R. (2010). Mother really knows best: host choice of adult phytophagous insect females reflects a within-host variation in suitability as larval food. Chemoecology, 20(1), 35-42. doi:10.1007/s00049-010-0040-8

Whitehill, J. G. a, Popova-Butler, A., Green-Church, K. B., Koch, J. L., Herms, D. a, \& Bonello, P. (2011). Interspecific proteomic comparisons reveal ash phloem genes potentially involved in constitutive resistance to the emerald ash borer. PloS one, 6(9), e24863. doi:10.1371/journal.pone.0024863

Woods, F. W., \& Shanks, R. E. (1959). Natural replacement of chestnut by other species in the Great Smoky Mountains National Park. Ecology, 40(3), 349-361. 


\section{Preface}

This thesis addresses one of the growing concerns and issues in ecology today. Through researching invasive species and plant ecology during my graduate and undergraduate programs I have become passionate about understanding our natural resources and properly managing threatened resources. Raising awareness regarding invasive species is important to the restoration of natural communities and promotion of conservation to recreationalist, landowners, and the next generation of ecologists. This research had applicable outcomes including the grouping of threatened ash trees into tolerance groups, tracking individuals over time, and identifying variation in host characteristics and host use in a population of infested trees. This research was conducted by myself with the guidance of my advisor Dr. Andrew J. Storer. Dr. Jordan M. Marshall was a crucial contributor towards data collection, data analysis, and written critiques. This thesis is planned for submission in the near future in hopes to contribute to the research and management regarding surviving ash trees in the face of emerald ash borer infestations. 


\section{Chapter 2 Evaluation and monitoring of ash (Fraxinus spp.) tolerant to long-term emerald ash borer (Agrilus planipennis [Coleoptera: Buprestidae]) exposure}

\section{Abstract}

Emerald ash borer (Agrilus planipennis [Coleoptera: Buprestidae]) is an invasive phloem-feeding pest which is responsible for the death of millions of ash (Fraxinus spp.) since it was first introduced in the mid-1990's in southeast Michigan. Over 200 surviving ash trees were identified in the Huron-Clinton Metroparks located in southeastern Michigan. A hierarchical cluster analysis generated three distinct groups from 176 trees based on similarities in crown dieback, vigor, and sign and symptom data from 2009. The apparently tolerant group $(n=67)$ had a mean crown dieback of $5.67 \%( \pm 0.21)$, the intermediate tolerance group $(n=57)$ had a mean dieback of $7.89 \%( \pm 0.79)$, and the not tolerant group $(n=52)$ had a mean dieback of $42.4 \%( \pm 3.98)$. The interaction between dieback, tolerance group, and year was significantly different. Approximately $75 \%$ of the trees in the apparently tolerant group did not decline in health over four years. Since 2010, the not tolerant group had significantly higher adult beetle landing rates than the apparently tolerant and the intermediate tolerance groups. Furthermore, the intermediate tolerance group had significantly different landing rates between years whereas the apparently tolerant and not tolerant groups did not. The apparently tolerant group had significantly lower emergence rates than the not tolerant group. However, larval success was not significantly different. These data suggest that apparently tolerant trees exist in the Metroparks and provide some indication of the mechanism behind tree survival. The differences in host tree response warrant further study and highlight the importance of preserving ash in infested areas. ${ }^{1}$

\footnotetext{
${ }^{1}$ The material contained in this chapter is planned for submission in the near future to Environmental Entomology.
} 


\section{Introduction}

Emerald ash borer, Agrilus planipennis Fairmaire (Coleoptera: Buprestidae), is a destructive invasive pest of North American ash (Fraxinus spp.) native to Asia. Since it was first discovered in Detroit, Michigan in 2002 (Haack et al. 2002, Cappaert et al. 2005), it has led to major economic losses, causing an estimated annual damage of $\$ 1.7$ billion per year (Aukema et al. 2011). The artificial spread of emerald ash borer has resulted from the movement of infested ash products such as nursery stock, firewood, and logs (Haack et al. 2010, Petrice and Haack 2011). As of 2013, this pest has been identified in 18 U.S. states and two Canadian provinces, Ontario and Quebec (www.emeraldashborer.info 2013). The high mortality rates attributed to emerald ash borer (Poland and Mccullough 2006, Poland 2007) suggest that ash trees and their ecological function are threatened or have already been lost. Aerial survey imagery from 2007 estimated that 24 million ash were dead and an additional 38 million ash were infested in southeast Michigan, northern Indiana, and northern Ohio (Marshall et al. 2013). However, approximately $85 \%$ of the 295 million live ash identified in these areas did not have signs and symptoms of emerald ash borer, suggesting that much of the impact of the insect was still to occur (Marshall et al. 2013).

Emerald ash borer threatens the presence of ash in urban and forested areas. The significant mortality caused by emerald ash borer is capable of altering community structure, forest composition, and native arthropod communities that are associated with ash (Gandhi and Herms 2010a). Research regarding emerald ash borer has in part focused on the early stages of infestation (e.g. Marshall et al. 2012), trapping techniques (e.g. Anulewicz et al. 2008, Marshall et al. 2009b, Pureswaran and Poland 2009) and interspecific resistance related to foliar and phloem chemistry (e.g. Eyles et al. 2007, Rebek et al. 2008, Chen et al. 2011b, Chamorro et al. 2012). Phenolic compounds differ between North American ash and Asian ash species, but the specific resistance mechanisms behind observed interspecific variation in resistance are still unknown (Cipollini et al. 2011). 
Emerald ash borer completes its life cycle in one or two years (Liu et al. 2007, Wei et al. 2007). In its native range, in northeastern China, Korea, Japan, Mongolia, Taiwan, and eastern Russia, adults primarily attack stressed trees, but in North America, apparently healthy ash are also attacked (Haack et al. 2002, Wei et al. 2007, Rebek et al. 2008). In southern Michigan, adults emerge in early May and feed on foliage for approximately two weeks causing minimal damage to the host tree (Haack et al. 2002, Poland and McCullough 2006). Eggs are laid in bark crevices, and on hatching the larvae tunnel into the bark of the tree (Wang et al. 2010). The larvae feed on the phloem and cambium of ash trees, which disrupts the flow of nutrients in the tree (Pureswaran and Poland 2009, Chen et al. 2011a). Extensive larval feeding can cause tree death in one to three years, though trees may remain below the detection threshold for several years as they lack external signs and symptoms of infestation (Poland and Mccullough 2006). External signs and symptoms of emerald ash borer infestation include D-shaped exit holes from emerging adults, splits in the bark resulting from the response of the host to feeding larvae, woodpecker damage, and physiological stress such as epicormic shoots and crown dieback.

Low-density infestations may be overlooked because external symptoms and signs are seen on heavily infested trees that have been infested for a number of years. Trapping of adults and/or peeling trees to look for larvae is more labor intensive but can positively detect infestations at an earlier stage than can be achieved using ground surveys (Marshall et al. 2009).

Dendrochronological data suggest that trees, near the original infestation, in the metro-Detroit area have been exposed to emerald ash borer for over 20 years (Siegert et al. 2007). Recently, surviving ash have been identified in these areas in southeast Michigan, despite long-term exposure to emerald ash borer (Marshall et al 2013). Digital aerial sketch mapping was used to identify individuals and groups of surviving ash in the Huron-Clinton Metroparks in southeast Michigan, and more than 200 surviving ash trees were visited and visually assessed in 2009 (Marshall et al. 2013). Trees with smooth bark were more likely to remain alive after exposure to emerald ash borer than trees with rough bark (Marshall et al. 2013). These findings suggest that 
there is variation in host tolerance and that a physical phenotype or a combination of multiple factors serve as the underlying mechanism.

High rates of mortality were seen in North American ash cultivars throughout a three year plantation study and low rates of mortality were seen in Manchurian ash ( $F$. mandshurica Rupr) (Rebek et al. 2008) suggesting that resistance in North American ash species is negligible. In similar areas that have been infested for prolonged periods of time, such as northern Ohio, $99 \%$ mortality was seen in some forested areas within six years after the first observation of an emerald ash borer infestation (Knight et al. 2013). However, the survival of individual trees within the Metroparks suggests some intraspecific variation in the quality of North American ash trees as a suitable host for emerald ash borer. It is evident that some trees in these Metroparks have been host to many feeding larvae, while adjacent trees have few or no signs of larval feeding (Marshall et al. 2013). The fact that a number of trees have survived in heavily infested areas suggest that ash may be able to persist on the landscape.

Overall goals of this study were to improve understanding of tree tolerance and survival patterns within an infested population of ash and identify the stages of the emerald ash borer life cycle that are interrupted in surviving trees. We used the previously identified population of surviving ash located in the Huron-Clinton Metroparks (Marshall et al. 2013) because trees in this area have been exposed to emerald ash borer since its discovery (Haack et al. 2002). Specific objectives were to 1) compare changes in tree condition (e.g. percent crown dieback and vigor rating), visual assessments of emerald ash borer signs and symptoms (e.g. bark splits, exit holes, woodpecker damage, and epicormic shoots), and landing behavior between different tolerance groups over time; 2) test for differences in bark roughness values between the tolerance groups; and 3) compare emerald ash borer emergence rates and larval success between tolerance groups. 


\section{Methods}

Field sites

The Huron-Clinton Metroparks consist of 13 individual parks in southeastern Michigan contained within the Huron River watershed. The study sites for this work were five of these metroparks: Kensington $\left(42.528951^{\circ} \mathrm{N} 83.655001^{\circ} \mathrm{W}\right)$, Lower Huron $\left(42.175036^{\circ} \mathrm{N} 83.427647^{\circ} \mathrm{W}\right)$, Willow $\left(42.138028^{\circ} \mathrm{N} 83.375325^{\circ} \mathrm{W}\right)$, Oakwoods $\left(42.1065^{\circ} \mathrm{N} 83.348186^{\circ} \mathrm{W}\right)$, and Lake Erie $\left(42.070617^{\circ} \mathrm{N} 83.210811^{\circ} \mathrm{W}\right)$. An aerial survey was completed in 2008 , using digital sketch mapping, to identify surviving ash trees in the metro-Detroit area (Marshall et al. 2013).

Two hundred and three surviving ash trees were identified throughout these parks. These trees were revisited annually over the previous four years to assess their condition and emerald ash borer signs and symptoms (Marshall et al. 2013). We identified an additional 52 live ash trees in 2011, within the same area and level of exposure to emerald ash borer. All study trees were located in patches of forest, along trails, and near the Huron River.

Assessment of tree condition over time

All trees in this study were previously identified by species, green ash (Fraxinus pennsylvanica Marshall) represented $90 \%$ of the trees and white ash (Fraxinus americana L.) accounted for the remaining 10\% (Marshall et al. 2013). Diameter at breast height (DBH) was recorded using a diameter-tape $(\mathrm{cm})$. Crown dieback and tree vigor were assessed annually in July from 2009 to 2012 using the USDA Forest Service rating system (Schomaker et al. 2007). Visual approximations of recent dieback were assessed in $5 \%$ crown dieback classes. Estimates of dieback were based on dead twigs and branches in the upper and outer edges of the tree crown, with a higher percent crown dieback indicating higher levels of tree stress. Tree vigor was evaluated using a vigor scale of 1-6, where 1 represents a healthy crown with few dead twigs, 2 represents a healthy crown with an occasional large dead branch, 3 represents moderate dieback, 4 represents approximately half of a dead crown, and 5 represents more than half of the 
crown dead (Schomaker et al. 2007). Trees with no live crown received a vigor rating of 6 , which is classified as a standing dead tree with branches intact.

Emerald ash borer signs and symptoms were recorded as binary values (0 or 1$)$ indicating the presence or absence of any of the following: bark-splits, D-shaped exit holes, woodpecker damage on the main stem and upper portion of the tree, and epicormic shoots on the base of the tree and main stem. Data from the tree assessments were used to separate trees into three tolerance groups: apparently tolerant, intermediate tolerance, and not tolerant.

Digital photographs were taken of the bark of 192 of the 203 ash trees identified in the 2009 survey and these images were then converted into bark roughness values based on the percent of black pixels (Marshall et al. 2013). The higher the number of pixels the rougher the bark, whereas the lower the number of pixels the smoother the bark.

\section{Emerald ash borer landing behavior}

To evaluate adult landing behavior, sticky band traps were set to collect adult beetles on trees in infested areas within each of the following five Metropark sites: Lake Erie, Lower Huron, Kensington, Oakwoods, and Willow. Forty-two sticky band traps were set in 2010 and 215 sticky band traps were set in 2011 and 2012 similar to the procedures taken by Marshall et al. (2009). All sticky band traps were set prior to the flight season in late April or early May and removed at the end of the flight season in late August. The emerald ash borer flight season begins with adult emergence between 400-500 growing degree days (GDD), which is the summation of the difference between the mean daily temperature and a base temperature of $10^{\circ} \mathrm{C}$ (USDA-APHISARS-FS 2010). Landing behavior study trees, including both green ash ( $F$. pennsylvanica) and white ash ( $F$. americana), were wrapped with a $0.5 \mathrm{~m}$ wide plastic band centered at breast height. The plastic wrap was covered with Tangle-Trap Coating (The Tanglefoot Co., Grand Rapids, MI) during the initial trap set up. Beetles were collected approximately every fourth week throughout 
the flight season from 2010-2012. Tangle-Trap Coating was reapplied mid-season to ensure stickiness.

Evidence of emerald ash borer emergence

Exit hole surveys were conducted on 38 randomly selected trees. Exit hole surveys were derived from the methods used in experiments with birch tree (Betula spp.) resistance to bronze birch borer (Agrilus anxius Gory [Coleoptera: Buprestidae]) (Nielsen et al. 2011). D-shaped exit holes were marked with a paint pen, on a $0.6 \mathrm{~m}$ section area above the sticky bands on the landing behavior study trees, in April 2012 prior to emergence and again in August, after 2012 emergence. Different colored pens were used to differentiate exit holes from the current season and exit holes from prior seasons. Additionally, previous woodpecker damage and exit holes from other borers were identified and marked separately.

\section{Success of larval establishment}

Egg deployments were conducted on a random sub-sample of 30 trees, 9 trees were in the apparently tolerant group, 11 in the intermediate tolerance group, and 10 in the not tolerant group. Eggs were deployed on half of the randomly selected trees from each tolerance group in June 2012 and on the remaining trees in July 2012. Emerald ash borer eggs were obtained from lab reared adult beetles from the USDA-APHIS-PPQ Biocontrol Rearing Facility (Brighton MI, APHIS) and deployed according rearing facility protocol and described briefly here. Female emerald ash borer oviposited eggs on coffee filter paper at the rearing facility. The eggs were kept in a climate controlled room with the following conditions: day temperature at $26.5^{\circ} \mathrm{C}$, night temperature $22.5^{\circ} \mathrm{C}, 16: 8 \mathrm{~L}: \mathrm{D}$ cycle, and $75 \%$ relative humidity. Eggs were kept in these rooms until 2-4 days from hatching, increasing the chance of successful establishment in the field.

Eggs were deployed using the coffee filters on which the eggs were laid. These filters were cut around the egg into $1 \times 1 \mathrm{~cm}$ pieces and placed egg-side towards the tree. The pieces were held to the tree with Parafilm, potentially protecting eggs from predators and the 
environment (Jon Lelito, USDA APHIS, personal communication). Each egg introduction point received 1-2 eggs, depending on the density of eggs on the filter paper pieces. Introductions were made onto trees at a rate of one introduction per $2 \mathrm{~cm}$ of $\mathrm{dbh}$. Trees ranged from $9 \mathrm{~cm}$ to $34 \mathrm{~cm}$ $\mathrm{dbh}$, and therefore the number of introduction points per tree ranged from 5 to 17 . Eggs were marked with a paint pen directly below the Parafilm wrap to facilitate larval extraction when portions of the trees were dissected to recover larvae.

Eggs were introduced on June 19, 2012 (159 eggs total) and on July 16, 2012 (163 eggs total). One quarter of the June deployed eggs were dissected, two months after deployment, in August and the remaining introduction points were dissected, after four months, in October. The July introduction points were all dissected, after three months, in October 2012. Introduction points were dissected and emerald ash borer larvae was collected by cutting windows in the infested trees with a draw knife or utility knife (Figure 1). The bark was carefully removed as the windows were peeled and inspected for feeding galleries and larvae. All larvae were collected and stored in vials with $70 \%$ ethanol and transported back to the lab at Michigan Technological University, Houghton, MI. Recovered larvae were then sorted by developmental stages (Chamorro et al. 2012). Six control windows were peeled and defined as control windows because eggs were not deployed on these trees. In order to duplicate methods, three control windows were peeled in August and three were peeled in October.

\section{Data analysis}

The entire dataset consisted of 224 trees that required a reduction in number before a cluster analysis could be performed. Trees with missing data were excluded immediately. Twenty-seven of the 203 trees identified in 2009 did not have adequate data in 2011 or 2012 and were dropped from the analysis. These trees were either missed during data collection, dead, or removed during the study. If trees were dead or missed during the 2012 season then data from the most recent year was used to represent these trees. The measured variables from a total of 176 trees were used track individual trees and changes in host condition (e.g. dieback and vigor) 
and use (e.g. landing rates) over a four year period. Nineteen of the 176 trees were dead as of 2012. A hierarchical cluster analysis grouped similar trees into distinct tolerance levels based on similarities in condition in 2009.

Binary data and continuous data were normalized to compare across categories. $\mathrm{R}$ package 3.0.2. (R. Development CoreTeam 2008) was used for the cluster and comparative analyses. A hierarchical clustering method was performed using dieback, vigor, and presence of signs and symptoms, with a flexible beta using a distance matrix between the variables. At each generation of clusters, trees were merged into larger clusters to minimize the within-cluster variation and to maximize the between-cluster variation. Our goal was to place the trees into three tolerance groups: apparently tolerant, not tolerant and intermediate tolerance.

Over 200 trees were assessed over time in this study, and 176 of these trees had data collected in all years and were used in this analysis. The individual trees were repeatedly measured over four years and since data for each year were not independent, a repeated measures analysis of variance (ANOVA) was used to detect differences in crown dieback by tolerance group over time.

A chi-square test was used to test the null hypothesis that tree vigor (1 vs. > 1) in 2012 was independent of the three tolerance groups created by the cluster analysis. Signs and symptoms were quantified as presence or absence on each tree surveyed from 2009-2012. Chisquare tests were used to test the hypothesis that the presence of a sign or symptom, specifically bark splits, exit holes, woodpecker damage, and epicormic shoots, in 2012 was independent of the clustered groups created using 2009 data.

Trapping surface area was calculated and used to determine landing rates of emerald ash borer adults per meter squared (adults $\left./ \mathrm{m}^{2}\right)$. A Kruskal-Wallis test was used to compare 1) landing rates between tolerance groups and 2) landing rates within a tolerance group between 
multiple years. If the test was significant then a post-hoc test described by Siegel and Castellan (1988) were used to determine which of the pairs of tolerance groups were significantly different.

An analysis of variance (ANOVA) was used to detect differences in bark roughness values between tolerance groups. Exit hole survey area was calculated to compare emerald ash borer emergence rates per meter squared $\left(\right.$ exit hole $\left./ \mathrm{m}^{2}\right)$ between tolerance groups. A KruskalWallis test was used to compare emergence rates and the proportion of larval success between groups. The methods described by Siegel and Castellan (1988) were followed for post-hoc analyses (Siegel and Castellan 1988).

\section{Results}

Using a hierarchical cluster analysis approach a dendrogram was generated and three clusters were identified. One hundred and seventy six trees were used and clusters were based on host tree similarities, including dieback, vigor, and sign and symptom data from 2009. Data was normalized prior to the cluster analysis. The healthiest group of trees $(n=67)$ had the lowest mean crown dieback of $5.67 \%( \pm 0.21)$ and was labeled as apparently tolerant (Figure 4). A second group of trees $(n=57)$ fell into the middle group with a mean crown dieback of $7.89 \%( \pm$ $0.79)$ and were designated as intermediate tolerance (Figure 2). The third group $(n=52)$ was the least healthy cluster which had the highest crown dieback of $42.4 \%( \pm 3.98)$ and was labeled not tolerant (Figure 3). The apparently tolerant group and the intermediate tolerance group had a median vigor rating of 1 in 2009 and the not tolerant group had a median vigor rating of 3 (Figure $6)$.

A repeated measures ANOVA was conducted to compare the effect of tolerance group on crown dieback in 2009 through 2012. Crown dieback was significantly different between tolerance groups $(F=120.6, d f=2, P<0.001)$ and between years $(F=59.75, d f=3, P<0.001)$. The interaction between tolerance group and year was significant $(F=14.78, d f=6, P<0.001)$ (Figure 5). 
The number of healthy trees with a vigor rating of 1 was significantly different between tolerance groups in $2012\left(\chi^{2}=57.32\right.$, d.f. $\left.=2, P>0.001\right)$. Of the trees in the apparently tolerant group, $74.6 \%$ did not see a decline in health over a four year time period and retained a vigor rating of 1 in 2012. In the intermediate tolerance group, 38.6\% of the trees had a vigor rating of 1 in 2012 and $5.7 \%$ of the trees in the not tolerant group had a vigor rating of 1 in 2012 (Figure 6).

The presence of signs and symptoms in 2012 were dependent on the tolerance group to which trees were assigned based on 2009 assessment data. The presence of bark splits in 2012 $\left(\chi^{2}=32.92\right.$, d.f. $\left.=2, P>0.001\right)$ was not independent of tolerance group (Figure 7$)$. The presence of exit holes in $2012\left(\chi^{2}=52.38\right.$, d.f. $\left.=2, P>0.001\right)$ was not independent of tolerance group (Figure 8). The presence of woodpecker damage in $2012\left(\chi^{2}=42.67\right.$, d.f. $\left.=2, P>0.001\right)$ was not independent of tolerance group (Figure 9). The presence of epicormic shoots in $2012\left(\chi^{2}=26.67\right.$, d.f. $=2, P>0.001)$ was not independent of tolerance group (Figure 10).

Overall landing rates (beetles per meter squared trapping surface) were significantly different between tolerance groups $\left(\chi^{2}=43.61\right.$, d.f. $\left.=2, P<0.001\right)$. Subsequent pairwise comparisons of the mean ranks between groups indicated that the not tolerant group $(0.047$ beetles $/ \mathrm{m}^{2}$ ) had significantly higher landing rates, collectively since 2010, than the apparently tolerant group $\left(0.016\right.$ beetles $/ \mathrm{m}^{2}$, rank difference $\left.=76.98\right)$ and the intermediate tolerance group ( 0.011 beetles $/ \mathrm{m}^{2}$, rank difference $\left.=74.96\right)$. The difference in landing rates between the apparently tolerant and intermediate tolerance groups were not significant (rank difference $=$ 2.02).

The following analysis used landing rate data (beetles per meter squared trapping surface) for each individual year within a group. Landing rates were not significantly different across years in the apparently tolerant group $\left(\chi^{2}=1.34\right.$, d.f. $\left.=2, P=0.512\right)$ and the not tolerant group $\left(\chi^{2}=4.62\right.$, d.f. $\left.=2, P=0.099\right)$. The mean landing rates in the apparently tolerant group in 2010 were 0.0087 beetles $/ \mathrm{m}^{2}$, in 2011 were 0.0144 beetles $/ \mathrm{m}^{2}$, and in 2012 were 0.0185 
beetles $/ \mathrm{m}^{2}$. The mean landing rates in the not tolerant group in 2010 were 0.0939 beetles $/ \mathrm{m}^{2}$, in 2011 were 0.0371 beetles $/ \mathrm{m}^{2}$, and in 2012 were 0.0422 beetles $/ \mathrm{m}^{2}$. Landing rates in the intermediate tolerance group were significantly different between years $\left(\chi^{2}=7.84\right.$, d.f. $=2, P=$ 0.020). Subsequent pairwise comparisons between years in the intermediate tolerance group indicated that the number of adults caught in 2012 (mean $=0.0151$ beetles $/ \mathrm{m}^{2}$ ) was significantly higher than in 2011 (mean $=0.00636$ beetles $/ \mathrm{m}^{2}$, rank difference $\left.=16.48\right)$. However, 2012 (rank difference $=4.22)$ and 2011 (rank difference $=12.26$ ) were not significantly different from landing rates in $2010\left(\right.$ mean $=0.0086$ beetles $\left./ \mathrm{m}^{2}\right)$.

Differences in bark roughness between tolerance groups were not significant (KruskalWallis test, $\mathrm{n}=167, \chi^{2}=2.08, \mathrm{df}=2, \mathrm{P}=0.352$ ). Trees in the apparently tolerant group had a mean roughness value of $31.02( \pm 1.37)$, trees in the intermediate tolerance group had a mean roughness value of $33.38( \pm 1.44)$, and trees in the not tolerant group had a mean roughness value of $31.02( \pm 1.20)$.

Emerald ash borer emergence rates (exit holes per meter squared survey area) were significantly different between the three tolerance groups (Kruskal-Wallis test, $n=38, \chi^{2}=13.25$, $\mathrm{df}=2, \mathrm{P}=0.001)$. Trees in the apparently tolerant group $(n=14)$ had a mean of 0.003 exit holes $/ \mathrm{m}^{2}( \pm 0.003)$, trees in the intermediate tolerance group $(n=12)$ had a mean of 0.011 exit holes $/ \mathrm{m}^{2}( \pm 0.004)$, and trees in the not tolerant group $(n=12)$ had a mean of 0.047 exit holes $/ \mathrm{m}^{2}$ $( \pm 0.012)$. Subsequent pairwise comparisons of the mean ranks between groups indicated that the apparently tolerant group had significantly lower emergence rates than the not tolerant group (rank difference $=13.57)$. However, the apparently tolerant group (rank difference $=4.19)$ and the not tolerant group (rank difference $=9.38$ ) were not significantly different from the intermediate tolerance group. These results show that the fewest adults emerge per meter squared from trees in the apparently tolerant group and that the most adults emerge from trees in the not tolerant groups. 
Larvae failed to establish on five of the 30 trees that had eggs placed on them. Each of these trees had dead phloem and were found to be heavily infested with emerald ash borer even though they still had some live crown. These trees were removed from the data analysis. Proportions of larvae to number of eggs deployed were used to compare larval success across groups. The apparently tolerant group ( $n=8$ trees) had 43 introduction points, the intermediate tolerance group ( $n=11$ trees) had 84 introduction points, and the not tolerant group $(n=6$ trees) had 48 introduction points. Overall survival from the egg deployment were not significantly different among the three tolerance groups (Kruskal-Wallis test, $\mathrm{n}=25, \chi^{2}=1.81$, $\mathrm{df}=2, \mathrm{P}=$ 0.404 ), with mean proportions of retrieved larvae of $23.1 \%$ in the apparently tolerant group, $12.8 \%$ in the intermediate tolerance group, and $14.7 \%$ in the not tolerant group. There were three developmental stages of emerald ash borer larvae recovered in the study ranging between $2^{\text {nd }}$ (L2) instar to larvae in pre-pupal chambers. Fourth instar $\left(4^{\text {th }}\right)$ larvae were the most common, making up almost half of the larvae retrieved $(47 \%)$. While third $\left(3^{\text {rd }}\right)$ instar larvae consisted of about one-third $(33 \%)$, and second $\left(2^{\text {nd }}\right)$ instar larvae were least common making up about $20 \%$ of larvae collected.

\section{Discussion}

The Huron-Clinton Metroparks include over 200 surviving ash that have been exposed to emerald ash borer for nearly 20 years. Previous studies have found nearly $100 \%$ mortality for all North American ash exposed to infestation (Poland and Mccullough 2006, Kashian and Witter 2011). Three tolerance groups were identified through a hierarchical cluster analysis which used dieback, vigor, and signs and symptoms as proximity measures to represent the nearness of trees to each other in a cluster. Trees with high similarity were related and placed in the same cluster and trees with low similarity were placed in different clusters. Trees in the apparently tolerant group $(n=67)$ represent trees that had the lowest crown dieback $(6 \%)$, the healthiest vigor rating (1), and lowest occurrence of signs and symptoms as of 2009. The intermediate tolerance group $(n=57)$ consists of trees with a similar crown dieback of $(8 \%)$ and a vigor rating 
of 1 . Trees in the not tolerant group $(n=62)$ represent the least tolerant trees in this system with the highest crown dieback (42\%), a poor vigor rating (3), and the highest occurrence of signs and symptoms.

This study categorized trees into different tolerance levels based on similarities in host tree condition and suggests that trees in the more tolerant groups show less decline over four years. Crown evaluations such as dieback allowed for the quantitative assessment of current tree conditions which vary annually based on site condition, density, and external stress. Previous research has looked at the effect of host condition, such as percent crown dieback, and the intensity of emerald ash borer infestation and tended to find that trees with more dieback had higher infestations than trees with less dieback (Rebek et al. 2008, Marshall et al. 2009). Trees in the apparently tolerant group experienced the least health decline, since 2009 , while trees in the not tolerant group had the largest health decline since 2009. Although a decline in tree health, as seen with an increase in crown dieback, was seen in all three groups trees in the apparently tolerant group and the intermediate tolerance group represent healthy trees and experienced less decline than trees in the not tolerant group (Figure 5). This suggests that there may be some host characteristic that strongly influences host condition and the intensity of infestation.

While dieback is a useful indicator of recent mortality, vigor is a measure that includes the long term combination of abiotic and biotic factors (e.g. age, stand density, genetics, pest problems, climatic trends, light, water, nutrient availability, and management). Approximately $75 \%$ of the trees in the apparently tolerant group did not see a decline in health over a four year time period and retained a vigor rating of 1 in 2012. In the intermediate tolerance group 39\% of the trees had a vigor rating of 1 in 2012 and in the not tolerant group 6\% of trees had a vigor rating of 1 in 2012. The median vigor rating for trees in the apparently tolerant group maintained a vigor of 1 (healthy) over the course of four years, while trees clustered into the intermediate tolerance group and the not tolerant group both experienced a decline in health (increase in vigor rating) going from a vigor rating of 1 to 2 (intermediate tolerance group) and 3 to 5 (not tolerant group) 
(Figure 4), suggesting there are tolerant trees in southeastern Michigan. Differences in individual tree response over time suggest that individual trees with resilient characteristics have a strong ability to resist or recover from attacks. Resilient characteristics could include vigorous growth and low dieback which may permit callus tissue growth and phloem to reconnect after biotic stressors and wounding (Kilham 1964). Host tree resistance can account for up to $15 \%$ of emerald ash borer larvae mortality which occurs when larvae and/or galleries are overgrown with tree callus tissue (Duan et al. 2013).

The presence of emerald ash borer signs and symptoms were variable between tolerance groups suggesting that some ash trees may be tolerant of this invasive pest. The patterns observed here suggest that North American ash may survive the emerald ash borer epidemic due to natural variation and inherent resistance regardless of the lack of a coevolutionary relationship. This variation is evident since trees in the apparently tolerant group represents about a third of the trees in this study and had the lowest occurrence of infestation despite the fact that all groups have had the same exposure to emerald ash borer. These results indicate that certain trees have persisted through the emerald ash borer epidemic and that some underlying mechanism or a combination of factors can have an effect on the success or failure of the emerald ash borer life cycle. Insect host choice can shape a range of tolerance levels in a host population, which can apply selection pressure restructuring the plant population (Wennström et al. 2010). As individual trees survive the emerald ash borer epidemic, it is likely that these individual trees have tolerant characteristics. Tree tolerance could be expressed as low vigor rating (which corresponds to a healthy tree) and low crown dieback resulting from the tree being less attractive to adults emerald ash borer or able to respond faster to biotic stressors. The variation in host-response to this pest could be a result of genetic variability and a source of resilience.

Adult emerald ash borer preferentially land on stressed ash trees which are most attractive to them, while healthy or nearly dead trees are less attractive (Mccullough et al. 2009, 
Crook and Mastro 2010, Marshall et al. 2012). The results in this study further support previous findings. The not tolerant group had significantly higher landing rates than the apparently tolerant group or the intermediate group suggesting that more adults preferentially land on trees in the not tolerant group. Landing rates were not significantly different between years in both the apparently tolerant and not tolerant group suggesting that the trees in these groups did not experience physiological changes making them more or less attractive to adults. However, the intermediate tolerance group had significantly different landing rates between years suggesting that these trees are experiencing physiological changes or are becoming more stressed since 2010 . The condition of trees in the intermediate tolerance group has changed over the four years and has potentially become more attractive to adult emerald ash borer.

Previous research has looked at the effect of physical host characteristics (i.e. bark roughness) on the intensity of emerald ash borer infestation. Bark roughness values were used to create a survivability curve demonstrating that trees with rougher bark had a higher probability of mortality than trees with smoother bark (Marshall et al. 2013). Physical plant traits, such as bark roughness, can have an influence on host choice and oviposition location (Lyons et al. 2009). Some emerald ash borer behavior is shaped by physical host characteristics as beetles have been shown to find cover in bark cracks during bad weather (Silk et al. 2011). Additionally, female beetles were seven times more likely to oviposit on trees with rougher bark than on trees with primarily smooth bark (Wei et al. 2007). Trees with rougher bark may serve as more suitable hosts for ovipositing females by offering protection from desiccation, predation, and wind or rain events. While physical plant characteristics can shape host-choice interactions and oviposition preference, these behaviors cannot be explained by this alone (Jezorek et al. 2010). Male beetles rely heavily on visual cues when mate-finding (Lelito et al. 2007), but it is unclear to what extent adults use visual cues for host-finding. In this study, bark roughness did not differ significantly between the tolerance groups. 
Active host selection is not possible for the egg and larval stage, and therefore adult choice has a major impact on the fitness of offspring. A useful contribution in understanding infestation rates would be to identify the variable of "the interrupted life cycle stage". In this study, emergence rates were significantly higher in the not tolerant group suggesting that the fewest adults emerge per meter squared survey area from trees in the apparently tolerant group.

Rates of recovery of larvae from sites where eggs were deployed on trees were low but similar between the tolerance groups. These results demonstrate that larvae can survive on apparently tolerant trees which indicate that the emerald ash borer life cycle can potentially be completed on all available host trees. Since larval success was not significantly different between tolerance groups, the larval stage is not being interrupted in this population of surviving ash. Emerald ash borer larval success or feeding choice have been shown to not be affected by defensive compounds found in the phloem chemistry (Chen et al. 2011c, 2012). Although the life cycle could be completed, adults apparently preferentially choose some trees over others, seen by the variation in landing rates and emergence rates.

The damaging effect and the continued spread of emerald ash borer raises concerns about the beetle becoming a nation-wide pest in North America (Cappaert et al. 2005, Poland and Mccullough 2006) increasing the importance of identifying potentially tolerant ash. Almost onequarter of ash trees identified in $\mathbf{2 0 0 9}$ do not show any evidence of emerald ash borer infestation, even after 20+ years of exposure (Marshall et al. 2013). However, this represents a much lower proportion of the population of ash that existed in these areas prior to the arrival of emerald ash borer. The extent to which the apparently tolerant ash trees continue to survive is unknown. However, this population of trees that have survived in the presence of emerald ash borer for over two decades may represent a trend towards new approaches and the classification of tolerance levels of ash trees in emerald ash borer infested areas. 


\section{Literature cited}

Anulewicz, A. C., Mccullough, D. G., Cappaert, D. L., \& Poland, T. M. (2008). Host range of the emerald ash borer (Agrilus planipennis Fairmaire) (Coleoptera: Buprestidae) in North America: results of multiple-choice field experiments. Entomological Society of America, 37(1), 230-241.

Cappaert, D., Mccullough, D. G., Poland, T. M., \& Siegert, N. W. (2005). Emerald Ash Borer in North America: A Research and Regulatory Challenge. American Entomologist, 51(3), 152165.

Chamorro, M. L., Volkovitsh, M. G., Poland, T. M., Haack, R. a, \& Lingafelter, S. W. (2012). Preimaginal stages of the emerald ash borer, Agrilus planipennis Fairmaire (Coleoptera: Buprestidae): an invasive pest on ash trees (Fraxinus). PloS one, 7(3), e33185. doi:10.1371/journal.pone.0033185

Chen, Y., Ciaramitaro, T., \& Poland, T. M. (2011). Moisture content and nutrition as selection forces for emerald ash borer larval feeding behaviour. Ecological Entomology, 36(3), 344354. doi:10.1111/j.1365-2311.2011.01278.x

Chen, Y., Ulyshen, M. D., \& Poland, T. M. (2012). Differential utilization of ash phloem by emerald ash borer larvae: ash species and larval stage effects. Agricultural and Forest Entomology, 14(3), 324-330. doi:10.1111/j.1461-9563.2012.00572.x

Chen, Y., Whitehill, J. G. a, Bonello, P., \& Poland, T. M. (2011a). Differential response in foliar chemistry of three ash species to emerald ash borer adult feeding. Journal of chemical ecology, 37(1), 29-39. doi:10.1007/s10886-010-9892-1

Chen, Y., Whitehill, J. G. a, Bonello, P., \& Poland, T. M. (2011b). Feeding by emerald ash borer larvae induces systemic changes in black ash foliar chemistry. Phytochemistry, 72(16), 1990-8. doi:10.1016/j.phytochem.2011.07.003

Cipollini, D., Wang, Q., Whitehill, J. G. A., Powell, J. R., Bonello, P., \& Herms, D. A. (2011). Distinguishing defensive characteristics in the phloem of ash species resistant and susceptible to emerald ash borer. Journal of chemical ecology, 37(5), 450-9. doi:10.1007/s10886-011-9954-z

Coyle, D. R., Clark, K. E., Raffa, K. F., \& Johnson, S. N. (2011). Prior host feeding experience influences ovipositional but not feeding preference in a polyphagous insect herbivore. Entomologia Experimentalis et Applicata, 138(2), 137-145. doi:10.1111/j.15707458.2010.01083.x

Crook, D. J., \& Mastro, V. C. (2010). Chemical ecology of the emerald ash borer Agrilus planipennis. Journal of chemical ecology, 36(1), 101-12. doi:10.1007/s10886-009-9738-x

Duan, J. J., Bauer, L. S., Abell, K. J., Lelito, J. P., \& Van Driesche, R. (2013). Establishment and abundance of Tetrastichus planipennisi (Hymenoptera: Eulophidae) in Michigan: potential for success in classical biocontrol of the invasive emerald ash borer (Coleoptera: Buprestidae). Journal of Economic Entomology, 106(3), 1145-1154. doi:10.1603/EC13047 
Egusa, S., Nishida, T., Sawada, H., \& Fujisaki, K. (2008). Is selection of host plants by Plagiodera versicolora based on plant-related performance? Entomologia Experimentalis et Applicata, 128(2), 258-264. doi:10.1111/j.1570-7458.2008.00729.x

Eyles, A., Jones, W., Riedl, K., Cipollini, D., Schwartz, S., Chan, K., Herms, D. a, et al. (2007). Comparative phloem chemistry of Manchurian (Fraxinus mandshurica) and two North American ash species (Fraxinus americana and Fraxinus pennsylvanica). Journal of chemical ecology, 33(7), 1430-48. doi:10.1007/s10886-007-9312-3

Gandhi, K. J. K., \& Herms, D. a. (2010). North American arthropods at risk due to widespread Fraxinus mortality caused by the alien emerald ash borer. Biological Invasions, 12(6), 18391846. doi:10.1007/s10530-009-9594-1

Haack, R. A., Jendek, E., Liu, H., Marchant, K. R., Petrice, T. R., Poland, T. M., \& Ye, H. (2002). The Emerald Ash Borer: A New Exotic Pest in North America. Michigan Entomological Society, 47(3\&4), 1-5.

Haack, R. a., Petrice, T. R., \& Wiedenhoeft, A. C. (2010). Incidence of bark- and wood-boring insects in firewood: a survey at Michigan's Mackinac Bridge. Journal of Economic Entomology, 103(5), 1682-1692. doi:10.1603/EC10041

Jezorek, H. a, Stiling, P. D., \& Carpenter, J. E. (2010). Targets of an invasive species: oviposition preference and larval performance of Cactoblastis cactorum (Lepidoptera: Pyralidae) on 14 North American opuntioid cacti. Environmental entomology, 39(6), 1884-92. doi:10.1603/EN10022

Kilham, L. (1964). The relations of breeding yellow-bellied sapsuckers to wounded birches and other trees. University of California Press, 81(4), 520-527.

Knight, K. S., Brown, J. P., \& Long, R. P. (2013). Factors affecting the survival of ash (Fraxinus spp.) trees infested by emerald ash borer (Agrilus planipennis). Biological Invasions, 15(2), 371-383. doi:10.1007/s10530-012-0292-z

Lelito, J. P., Fraser, I., Mastro, V. C., Tumlinson, J. H., Böröczky, K., \& Baker, T. C. (2007). Visually Mediated "Paratrooper Copulations" in the Mating Behavior of Agrilus planipennis (Coleoptera: Buprestidae), a Highly Destructive Invasive Pest of North American Ash Trees. Journal of Insect Behavior, 20(6), 537-552. doi:10.1007/s10905-007-9097-9

Liu, H., Bauer, L. S., Miller, D. L., Zhao, T., Gao, R., Song, L., Luan, Q., et al. (2007). Seasonal abundance of Agrilus planipennis (Coleoptera: Buprestidae) and its natural enemies Oobius agrili (Hymenoptera: Encyrtidae) and Tetrastichus planipennisi (Hymenoptera: Eulophidae) in China. Biological Control, 42(1), 61-71. doi:10.1016/j.biocontrol.2007.03.011

Liu, Z., Scheirs, J., \& Heckel, D. G. (2012). Trade-offs of host use between generalist and specialist Helicoverpa sibling species: adult oviposition and larval performance. Oecologia, 168(2), 459-69. doi:10.1007/s00442-011-2103-0

Lyons, B. D., De Groot, P., Jones, G. C., \& Scharbach, R. (2009). Host selection by Agrilus planipennis (Coleoptera: Buprestidae): inferences from sticky-band trapping. The Canadian Entomologist, 141, 40-52. 
Marshall, J. M., Porter, M. J., \& Storer, A. J. (2012). Predicting emerald ash borer , Agrilus planipennis (Coleoptera: Buprestidae), landing behavior on unwounded ash. The Great Lakes Entomologist, 45(1 - 2), 29-39.

Marshall, J. M., Smith, E. L., Mech, R., \& Storer, A. J. (2013). Estimates of Agrilus planipennis infestation rates and potential survival of ash. American Midland Naturalist, 169, 179-193.

Marshall, J. M., Storer, A. J., Fraser, I., Beachy, J. A., \& Mastro, V. C. (2009). Effectiveness of differing trap types for the detection of emerald ash borer (Coleoptera: Buprestidae). Environmental Entomology, 38(4), 1226-1234.

Mccullough, D. G., Poland, T. M., Anulewicz, A. C., \& Cappaert, D. (2009). Emerald ash borer (Coleoptera: Buprestidae) attraction to stress or baited ash trees. Environmental Entomology, 38(6), 1668-1679.

Nielsen, D. G., Muilenburg, V. L., \& Herms, D. a. (2011). Interspecific variation in resistance of Asian, European, and North American birches (Betula spp.) to bronze birch borer (Coleoptera: Buprestidae). Environmental Entomology, 40(3), 648-53. doi:10.1603/EN10227

Petrice, T. R., \& Haack, R. A. (2011). Effects of cutting time, stump height, and herbicide application on ash (Fraxinus Spp.) stump sprouting and colonization by emerald ash borer (Agrilus planipennis). North J. Appl. For., 28(2), 79-83.

Poland, T. M. (2007). Twenty million ash trees later: current status of emerald ash borer in Michigan. Michigan Entomological Society, 52(April), 10-14.

Poland, T. M., \& Mccullough, D. G. (2006). Emerald ash borer : invasion of the urban forest and the threat to North America 's ash resource. Journal of Forestry, (April/May), 118-124.

Pureswaran, D. S., \& Poland, T. M. (2009). Host selection and feeding preference of Agrilus planipennis (Coleoptera: Buprestidae) on ash (Fraxinus spp.). Environmental Entomology, 38(3), 757-765. doi:10.1603/022.038.0328

R. Core Devlopement Team (2008). R: A language and environment for statistical computing. Vienna, Austria. Retrieved from http://www.r-project.org.

Rebek, E. J., Herms, D. A., \& Smitley, D. R. (2008). Interspecific variation in resistance to emerald ash borer (Coleoptera: Buprestidae) among North American and Asian ash (Fraxinus spp.). Environmental Entomology, 37(1), 242-246.

Schomaker, M. E., Zarnoch, S. J., Bechtold, W. A., Latelle, D. J., Burkman, W. G., \& Cox, S. M. (2007). Crown-condition classification: a guide to data collection and analysis (pp. 8-10). Asheville, North Carolina.

Schoonhoven, L. M., Van Loon, J. J. A., \& Dicke, M. (2005). Insect-Plant Biology (2nd ed., pp. 135-232). New York: Oxford University Press Inc.

Siegel, \& Castellan. (1988). Nonparametric Statistics for the Behavioral Sciences (pp. 213-214). New York: MacGraw Hill Int. 
Siegert, N. W., McCullough, D. G., Liebhold, A. M., \& Telewski, F. W. (2007). Resurrected from the ashes: a historical reconstruction of emerald ash borer dynamics through dendrochronological analysis. Emerald ash borer and Asian longhorned beetle research and development review meeting. Cincinnatti, OH. FHTET 2007-04. Morgantown, WV: U.S. Forest Service, Forest Health Technology Enterprise Team (pp. 18-19).

Silk, P. J., Ryall, K., Mayo, P., Lemay, M. a, Grant, G., Crook, D., Cossé, A., et al. (2011). Evidence for a volatile pheromone in Agrilus planipennis Fairmaire (Coleoptera: Buprestidae) that increases attraction to a host foliar volatile. Environmental entomology, 40(4), 904-16. doi:10.1603/EN11029

USDA-APHIS-ARS-FS. (2010). Emerald ash borer biological control release guidelines (pp. 1$67)$.

Wang, X.-Y., Yang, Z.-Q., Gould, J. R., Zhang, Y.-N., Liu, G.-J., \& Liu, E. (2010). The biology and ecology of the emerald ash borer, Agrilus planipennis, in China. Journal of insect science (Online), 10(128), 128. doi:10.1673/031.010.12801

Wei, X., Wu, Y., Reardon, R., Sun, T.-H., Lu, M., \& Sun, J.-H. (2007). Biology and damage traits of emerald ash borer (Agrilus planipennis Fairmaire) in China. Insect Science, 14(5), 367373. doi:10.1111/j.1744-7917.2007.00163.x

Wennström, A., Niemi Hjulström, L., Hjältén, J., \& Julkunen-Tiitto, R. (2010). Mother really knows best: host choice of adult phytophagous insect females reflects a within-host variation in suitability as larval food. Chemoecology, 20(1), 35-42. doi:10.1007/s00049-010-0040-8

www.emeraldashborer.info. (2013). Maps and State EAB information. Retrieved from http://www.emeraldashborer.info/map.cfm\#sthash.sHBqXBPh.qeajgPEl.dpbs

Xue, H.-J., Egas, M., \& Yang, X.-K. (2007). Development of a positive preference-performance relationship in an oligophagous beetle: adaptive learning? Entomologia Experimentalis et Applicata, 125(2), 119-124. doi:10.1111/j.1570-7458.2007.00605.x 


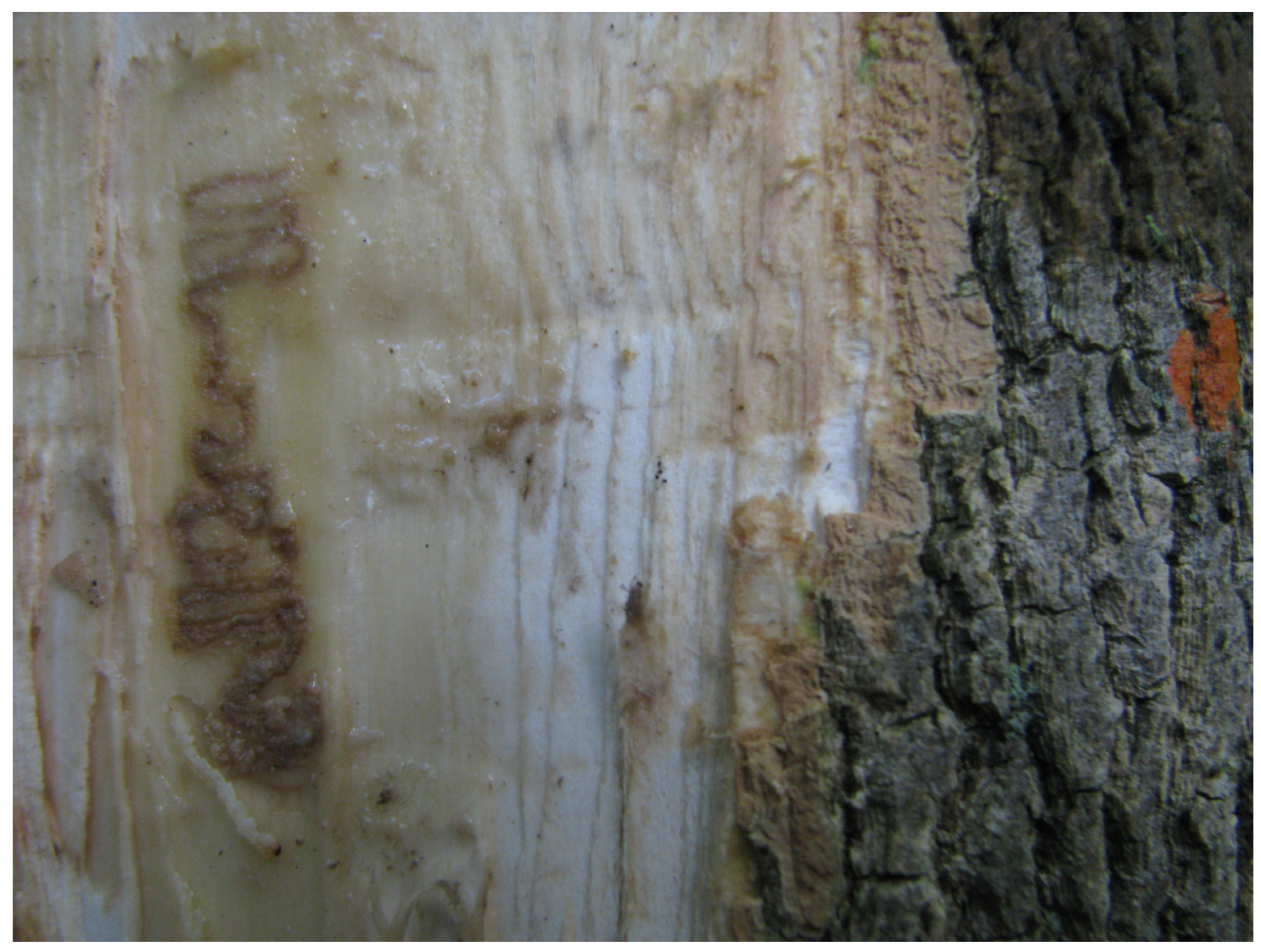

Figure 1. Emerald ash borer gallery from the egg deployment introduction points in the HuronClinton Metroparks in southeastern Michigan. Eggs were placed above the orange dots, near the right edge of the picture, and were dissected by cutting windows with a utility knife to retrieve larvae. 


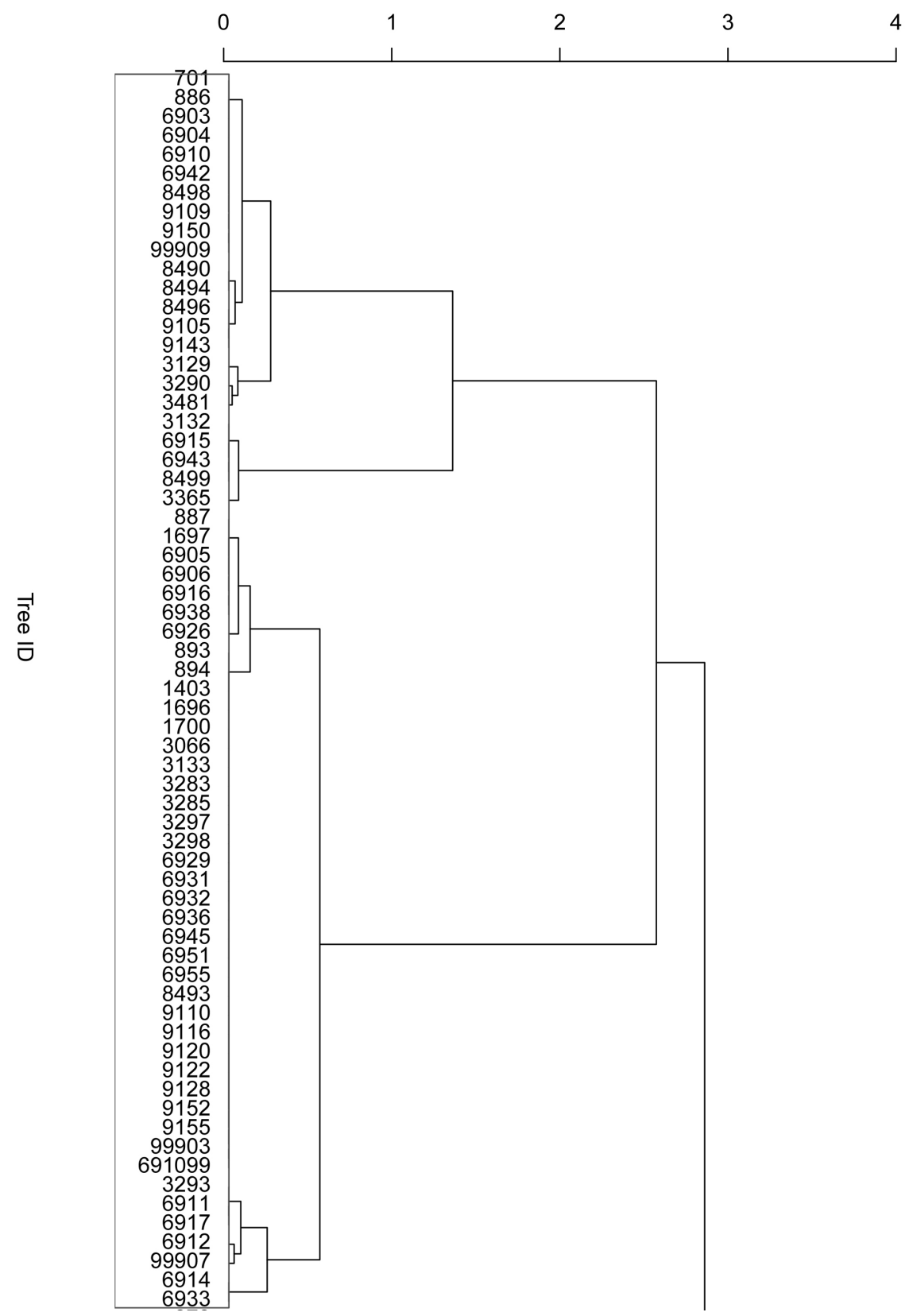

Figure 2. Individual trees in the intermediate tolerance group represented by the dendrogram generated using a hierarchical cluster analysis approach. One hundred and seventy six trees were used and clusters were based on host tree similarities, specifically including dieback, vigor, and sign and symptom data from 2009. Data was normalized prior to the cluster analysis resulting in three clusters: 1) apparently tolerant $(n=67), 2)$ intermediate tolerance $(n=57)$, and 3) not tolerant $(n=52)$. 


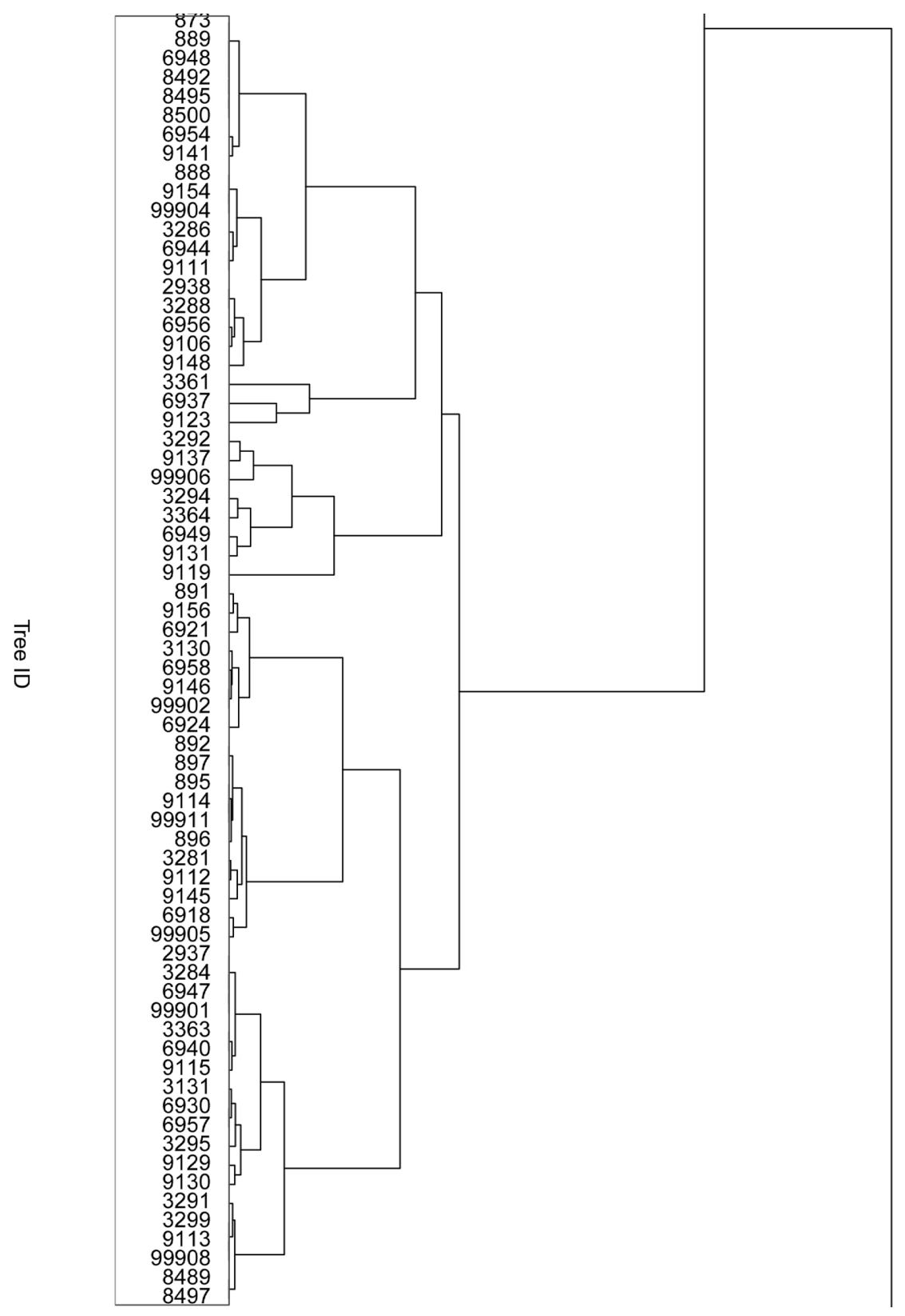

Figure 3. Individual trees in the not tolerant group represented by the dendrogram generated using a hierarchical cluster analysis approach. One hundred and seventy six trees were used and clusters were based on host tree similarities, specifically including dieback, vigor, and sign and symptom data from 2009. Data was normalized prior to the cluster analysis resulting in three clusters: 1 ) apparently tolerant $(n=67), 2)$ intermediate tolerance $(n=57)$, and 3$)$ not tolerant $(n$ $=52$ ). 


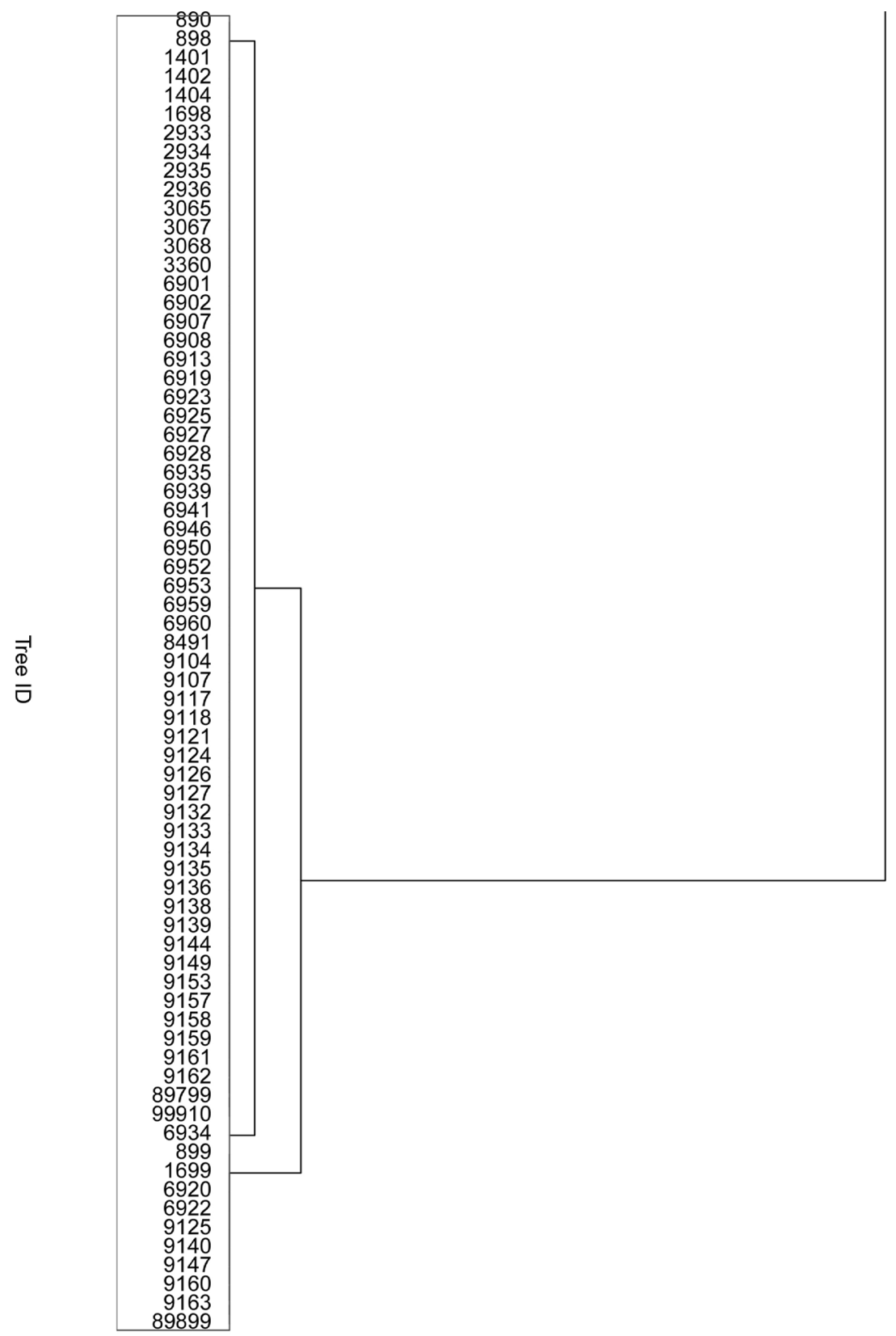

Figure 4. Individual trees in the apparently tolerant group represented by the dendrogram generated using a hierarchical cluster analysis approach. One hundred and seventy six trees were used and clusters were based on host tree similarities, specifically including dieback, vigor, and sign and symptom data from 2009. Data was normalized prior to the cluster analysis resulting in three clusters: 1$)$ apparently tolerant $(n=67), 2)$ intermediate tolerance $(n=57)$, and 3$)$ not tolerant $(n=52)$. 


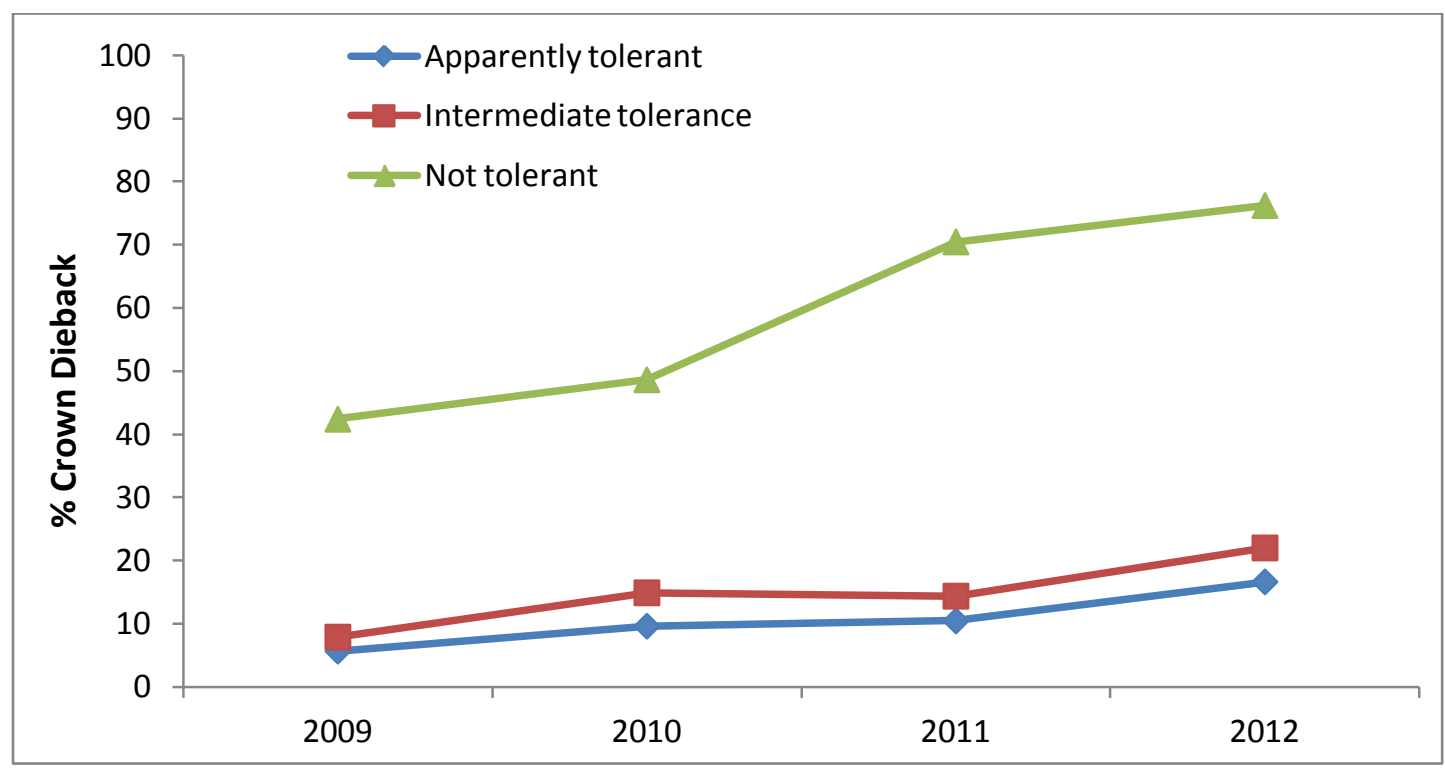

Figure 5. Mean percent crown dieback for 176 trees located in the Huron-Clinton Metroparks. A repeated measures ANOVA was conducted to compare the effect of tolerance group on crown dieback in 2009, 2010, 2011, and 2012. The interaction between dieback, tolerance group, and year was significant $(F=14.78, \mathrm{df}=6, \mathrm{P}<0.001)$. 


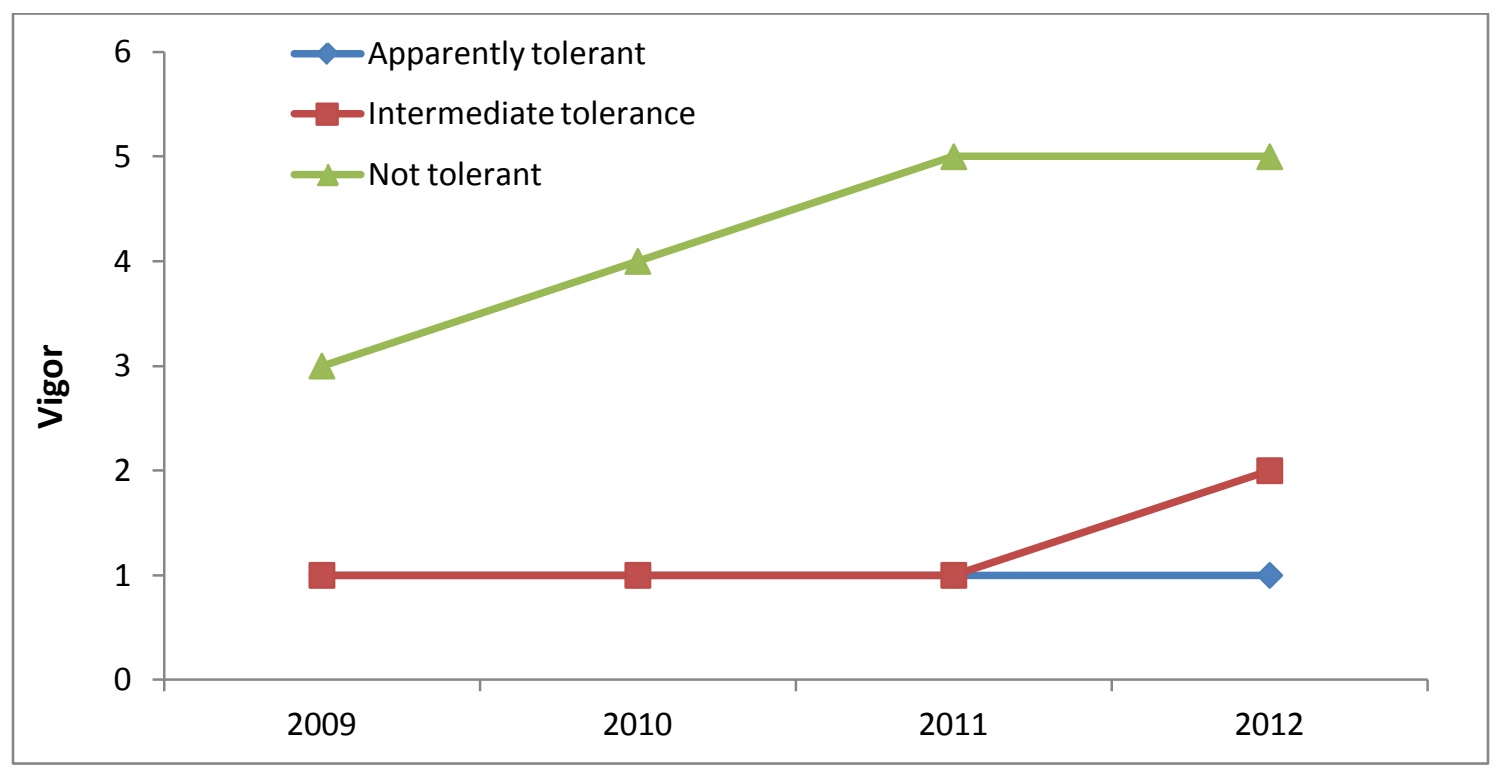

Figure 6. Median vigor rating for 176 trees located in the Huron-Clinton Metroparks. A hierarchical cluster analysis created three groups based on similarities and used for comparison of host condition over time. The number of healthy trees with a vigor rating of 1 was significantly different between tolerance groups $\left(\chi^{2}=57.32\right.$, d.f. $\left.=2, P>0.001\right)$. 


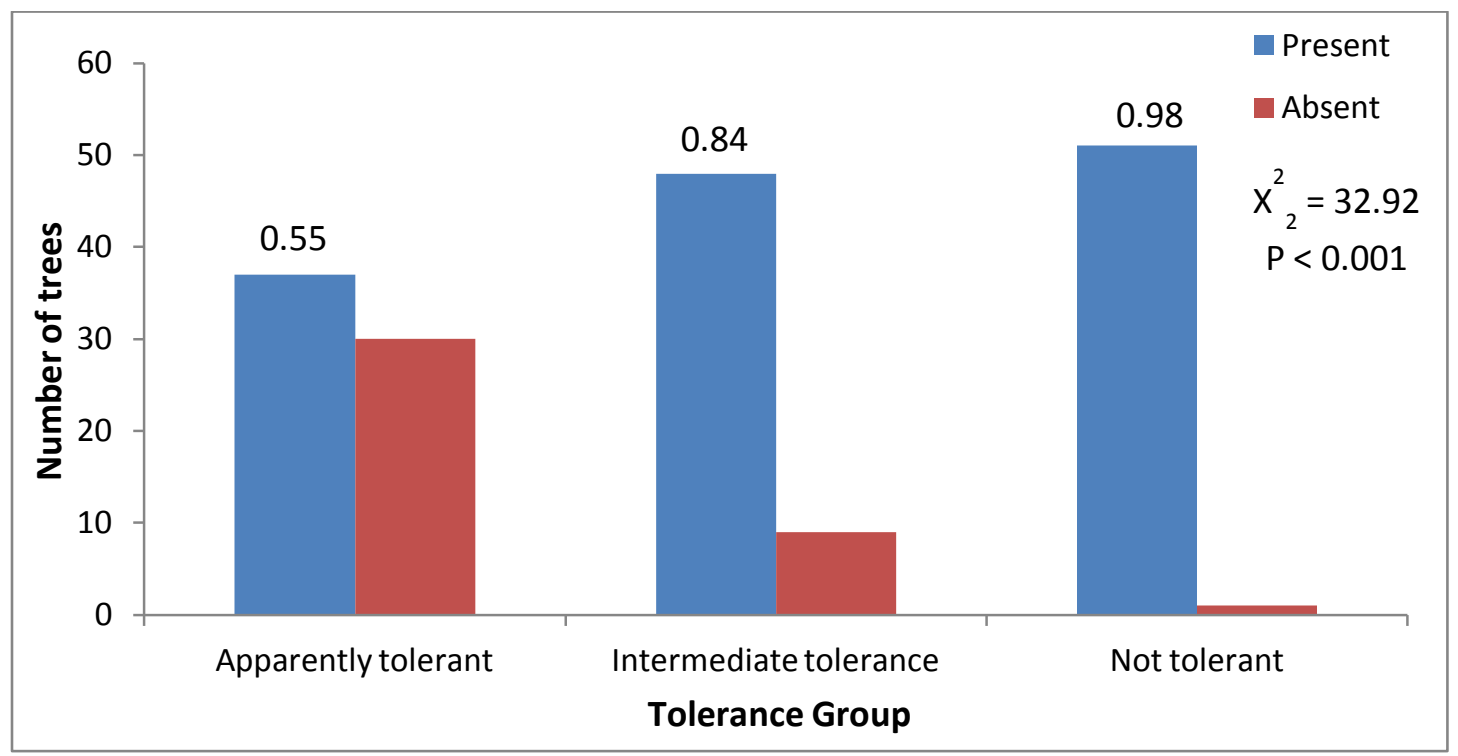

Figure 7. Number of trees with bark splits present (blue) and absent (red) in 2012 in long-term emerald ash borer infested sites. Proportions of trees with bark splits are presented above the bars. 


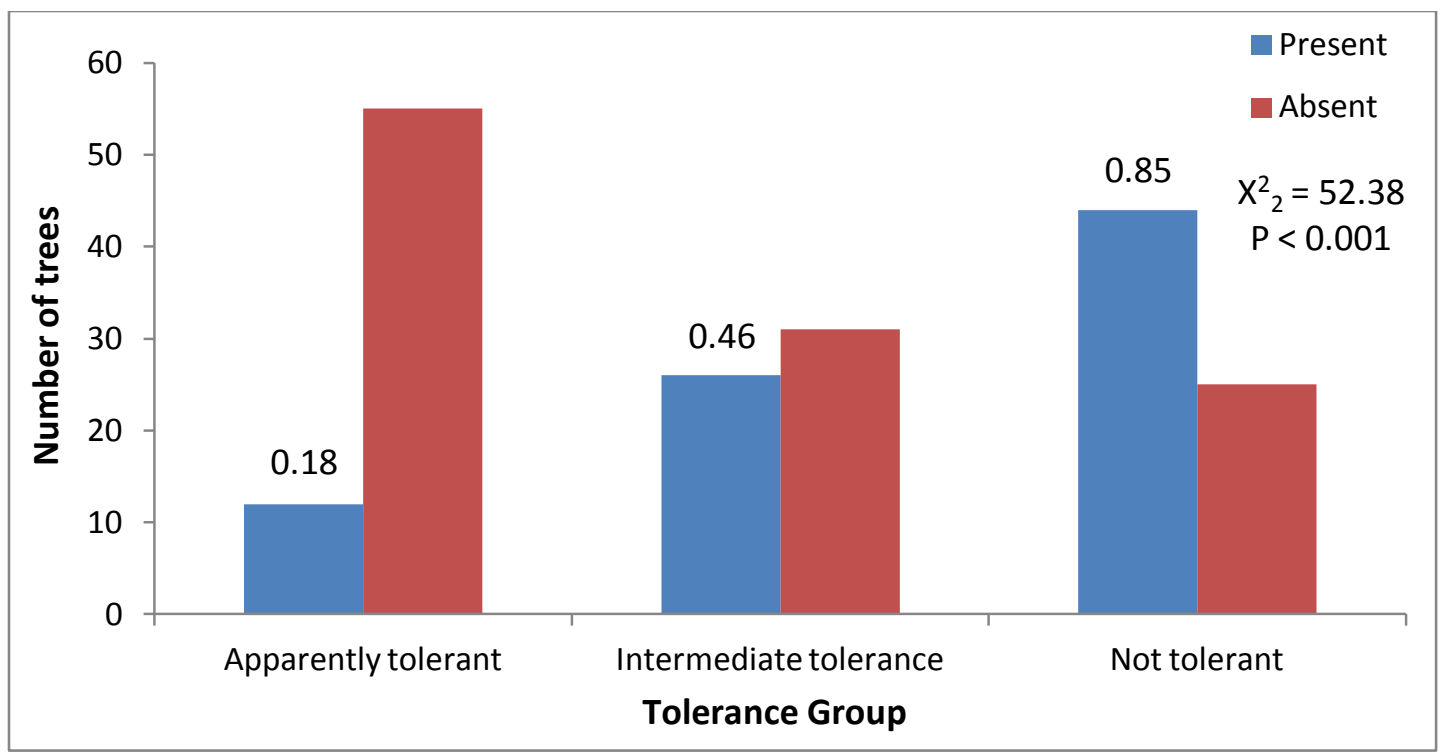

Figure 8. Number of trees with exit holes present (blue) and absent (red) in 2012 in long-term emerald ash borer infested sites. Proportions of trees with exit holes are presented above the bars. 


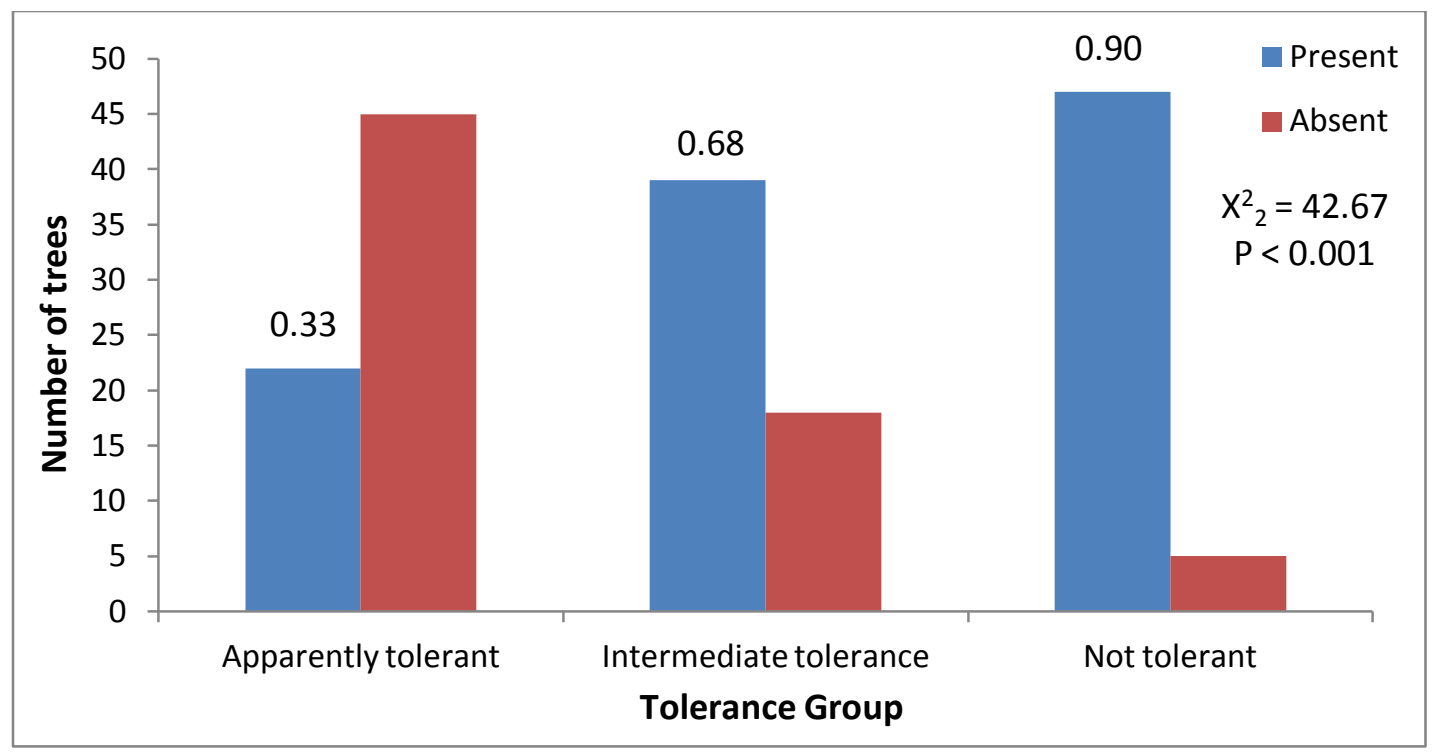

Figure 9. Number of trees with woodpecker damage present (blue) and absent (red) in 2012 in long-term emerald ash borer infested sites. Proportions of trees with woodpecker damage are presented above the bars. 


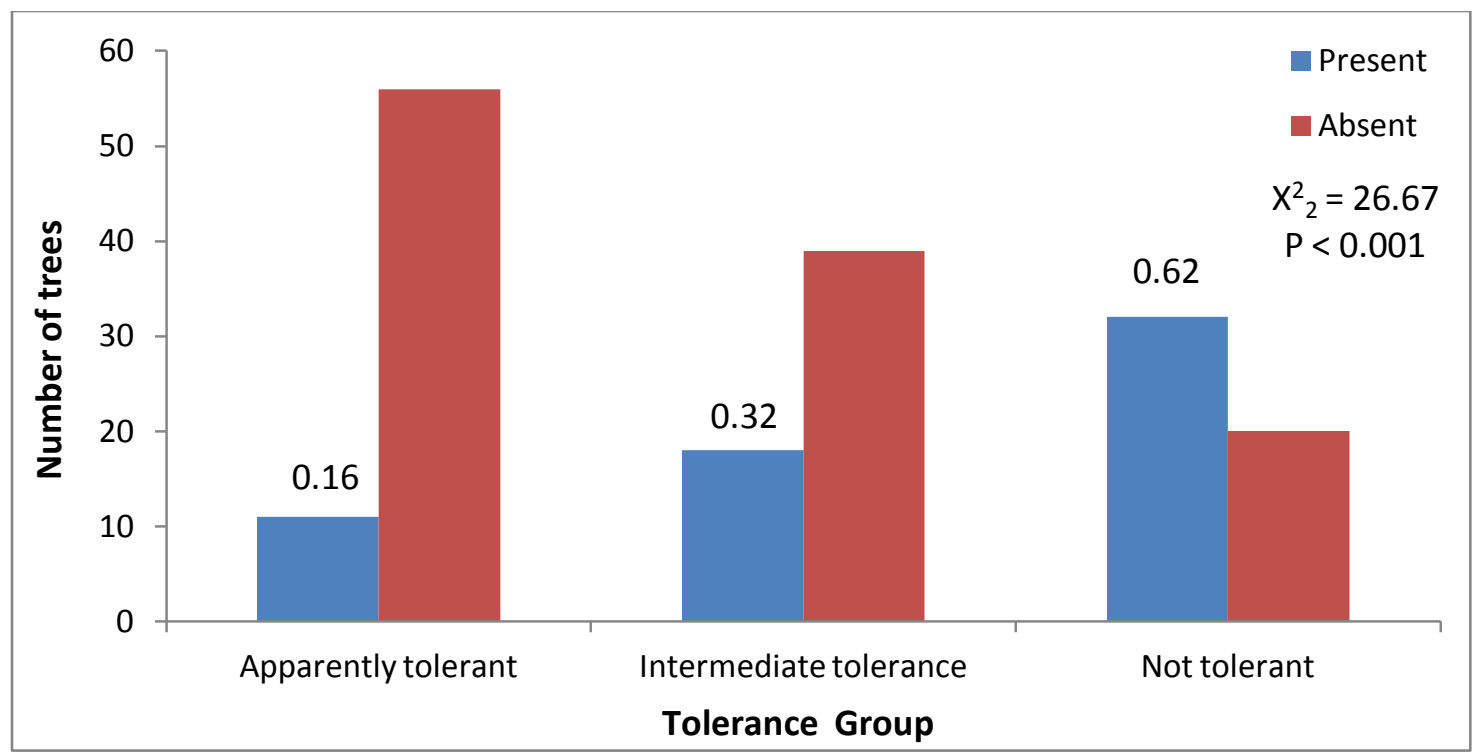

Figure 10. Number of trees with epicormic shoots present (blue) and absent (red) in 2012 in longterm emerald ash borer infested sites. Proportions of trees with epicormic shoots are presented above the bars. 